\title{
Abhandlung
}

Goce Naumov*, Aleksandar Mitkoski, Hristijan Talevski, Jana Anvari, Marcin Przybyła, Darko Stojanovski, Ferran Antolín, Amalia Sabanov, Ivana Živaljević, Vesna Dimitrijević, Juan F. Gibaja, Niccolò Mazzucco, Gjore Milevski, Nikola Dumurđanov, Jugoslav Pendić, Zlata Blažeska and Sofija Stefanović

\section{The Early Neolithic tell of Vrbjanska Čuka in Pelagonia}

https://doi.org/10.1515/pz-2021-0007

*Corresponding author: Goce Naumov, Center for Prehistoric Research/Goce Delčev University, Skopje/Štip, North Macedonia. E-Mail: goce.naumov@ugd.edu.mk

Aleksandar Mitkoski, NI Institute for Protection of Cultural Monuments and Museum-Prilep, North Macedonia. E-Mail: amitkoski@yahoo.com

Hristijan Talevski, PRI Institute of Old Slavic Culture-Prilep, North Macedonia. E-Mail: hristijan.talevski@isk.edu.mk

Jana Anvari, Department of Prehistoric Archaeology, University of Cologne, Germany. E-Mail: jana.anvari@uni-koeln.de

Marcin Przybyta, Archaeological company ,Dolmen` - Krakow, Poland. E-Mail: dolmen@onet.pl

Darko Stojanovski, BioSense Institute, University of Novi Sad, Serbia.E-Mail: stjdrk@unife.it

Ferran Antolín, Department of Natural Sciences, German Archaeological Institute, Berlin, Germany. E-Mail: ferran.antolin@dainst.de Amalia Sabanov, Laboratory for Bioarchaeology, University of Belgrade, Serbia. E-Mail: amaliasabanov@gmail.com Ivana Živaljević, BioSense Institute, University of Novi Sad, Serbia. E-Mail: ivana.zivavljevic@biosense.rs

Vesna Dimitrijević, BioSense Institute, University of Novi Sad/ Laboratory for Bioarchaeology, University of Belgrade, Serbia. E-Mail: vdimitri@f.bg.ac.rs

Juan F. Gibaja, Spanish School of History and Archaeology in Rome (EEHAR-CSIC), Italy. E-Mail:juan.gibaja@eehar.scic.es

Niccolò Mazzucco, Archaeology of Social Dynamics research group, Spanish Research Council for Scientific Research, Barcelona, Spain. E-Mail:nmazzucco@imf.csic.es

Gjore Milevski, Center for Prehistoric Research, Skopje, North Macedonia. E-Mail: gjoremilevski@gmail.com

Nikola Dumurđanov, Faculty of Mining and Geology, SS Cyril and Methodius University, Skopje, North Macedonia.

E-Mail: nikola_dumo@hotmail.com

Jugoslav Pendić, BioSense Institute, University of Novi Sad, Serbia. E-Mail: jugoslav.pendic@biosense.rs

Zlata Blažeska, Independent researcher, Prague, Czech Republic. E-Mail: zblazeska@hotmail.com

Sofija Stefanović, BioSense Institute, University of Novi Sad/

Laboratory for Bioarchaeology, University of Belgrade, Serbia.

E-Mail: sofija.stefanovic@biosense.rs
Zusammenfassung: Vrbjanska Čuka ist ein Tell in der Region Pelagonien (Mazedonien), der vor 8000 Jahren entstand. Während der Römerzeit und im Mittelalter fand hier Landwirtschaft statt, zudem wurde der Hügel als Grabstätte genutzt. Die in den 1980ern sowie während der letzten fünf Jahre erfolgten Ausgrabungen führten den Beleg einer neolithischen bäuerlichen Gesellschaft, die in einer von einem kreisförmigen Graben umschlossenen Siedlung große Gebäude aus Lehm errichtete. In den Gebäuden wurden zahlreiche Lehmstrukturen nachgewiesen, etwa Öfen, Getreidespeicher sowie Bereiche zur Verarbeitung von Getreide und die Herstellung von Brot. Die neolithischen Gemeinden nutzten qualitätvolle Töpferwaren, modellierten Figuren und Altäre, während die hier geborgenen Steinwerkzeuge hauptsächlich zum Fällen von Bäumen, zur Ernte oder für das Mahlen von Getreiden verwendet wurde. Neben Nahrungsmitteln aus Getreide (Einkorn, Emmer, Gerste) konsumierten die Einwohner von Vrbjanska Čuka Linsen, Erbsen und eine Vielzahl wildgesammelter Früchte. Die Ernährung bereicherten ferner Rind-, Ziege/Schaf- und Wildfleisch, außerdem Muscheln und Fisch sowie Milchprodukte. Der vorliegende Beitrag fasst eine Vielzahl von international und multidisziplinär ermittelten Daten zusammen. Diese basieren auf örtlichen Ausgrabungen, Prospektionen, geomagnetischen Untersuchungen, Studien zur materiellen Kultur, der Architektur, Radiokarbondatierungen, geoarchäologischen, archäobotanischen, archäozoologischen und Lipiduntersuchungen. Hinzu kommen Gebrauchsspuranalysen, Studien zur Topografie sowie 3D-Modellierungen. Die Untersuchungen in Vrbjanska Čuka erbrachten neues Wissen zum frühen Neolithikum in Pelagonien und tragen ferner zum umfassenderen Verständnis der ersten bäuerlichen Gesellschaften auf dem Balkan bei.

Schlüsselworte: Pelagonien; Neolithikum; Tells; bäuerliche Gemeinschaften; Ausgrabungen; Laboranalysen 
Abstract: Vrbjanska Čuka is a tell site in the region of Pelagonia (Macedonia) established 8000 years ago by the Neolithic communities. Later it was used as an agricultural unit during the Roman era and the Middle Ages when it was also employed as a burial area. The excavations performed in the 1980s and during the last five years indicate a Neolithic farming society that constructed large buildings made of daub in a settlement enclosed by a circular ditch. The buildings had many clay structures, such as ovens, granaries, bins and grinding areas for processing cereals and bread production. The Neolithic communities used sophisticated fine pottery and modeled figurines and altars, while the stone tools were mainly used for cutting trees, harvesting and grinding. Apart from the cereal-based food (einkorn wheat, emmer wheat or barley), the inhabitants of Vrbjanska Čuka consumed lentils, peas and a variety of gathered wild fruits, while cattle, caprovine, mussels, fish and wild game meat was also part of a diet, as well as the dairy products. This paper will be a summary of a variety of data provided from the current international and multidisciplinary research of the site that involves excavation, prospection, geomagnetic survey, study of material culture, examination of architecture, radiocarbon dating, geoarchaeological, archaeobotanical, archaeozoological, lipid and use-wear analyses, as well as the topographic and 3D modeling. The recent knowledge on Vrbjanska Čuka provides novel understanding of the Early Neolithic in Pelagonia and contributes to the more extensive research of first farming societies in the Balkans.

Keywords: Pelagonia; Neolithic; tells; farming societies; fieldwork; laboratory analysis

Апстракт: Врбјанска Чука претставува тумба во котлината Пелагонија (Македонија), основана од неолитските заедници пред 8000 години. Била користена како стопанска целина за време на Римската Империја, но и во текот на средниот век кога исто така функционирала и како некропола. Ископувањата вршени во 1980-те и во последните пет години укажуваат на неолитско земјоделско општество кое конструирало големи градби направени од лепеж во населба заштитена со кружен ров. Во градбите се наоѓале многу глинени конструкции, како што се печки, амбари, сандаци и места за мелење и обработка на житни култури при подготовка на леб. Неолитските заедници користеле софистицирана фина керамика и моделирани фигурини и жртвеници, додека камените алатки главно се користеле за сечење дрвја, жнеење и мелење. Освен храната на база на житни култури (еднозрнеста и двозрна пченица или јачмен), жителите на Врбјанска Чука исто така конзумирале леќа, грашок, разновидно овошје, говедско, овчо и свинско месо, школки, риба и месо од дивеч, како и млечни производи. Овој труд ќе биде резиме на различни податоци добиени од тековните меѓународни и мултидисциплинарни истражувања на локалитетот, а кои вклучуваат ископување, рекогносцирање, геомагнетно скенирање, проучување на материјалната култура, испитување на архитектурата, студии за функциите на алатките, радиојаглеродно датирање, геоархеолошка, археоботаничка, археозоолошка и липидна анализа, како и топографско и ЗД моделирање. Добиените сознанија за Врбјанска Чука даваат ново разбирање на раниот неолит во Пелагонија и придонесуваат за поопсежно истражување на првите земјоделски општества на Балканот.

Клучни зборови: Неолит, тумби, земјоделски општества, теренски истражувања, лабораториски анализи

\section{Introduction}

The Neolithization of the Balkans has been studied from different perspectives and various regions were considered in order to understand the modes and routes of its implementation among the first farming societies on this peninsula. One of these regions that was inhabited early on by the agricultural communities is Pelagonia, an elongated valley in Macedonia surrounded by diverse mountains. The initial interest in the prehistory of Pelagonia started in the first half of $20^{\text {th }}$ century, but the major research was done after World War II and particularly in the 1970s, when a number of excavations were performed on various tells, a major settlement feature in this region ${ }^{1}$. The archeological research in Pelagonia was significantly reduced in the three following decades ${ }^{2}$, but a novel interest started in 2010s when numerous excavations, prospection, geophysical surveys, studies of material culture and laboratory analyses were initiated by introducing current methods and scientific perspectives ${ }^{3}$. Such approaches, along with data obtained from 1970s, provided a new understanding of the region and the first farming communities that established a number of tells.

One of the tells that raised particular interest is Vrbjanska Čuka, a complex archaeological site in the north-

1 Grbić et al. 1960; Simoska/Sanev 1975; Simoska/Sanev 1976; Kitanoski 1977; Simoska/Sanev 1977; Simoska et al. 1979.

2 Kitanoski 1989; Simoska/Kuzman 1990;

3 Naumov et al. 2014; Naumov/Tomaž 2015; Naumov 2016a; Naumov et al. 2017a; Naumov et al. 2017b; Naumov et al. 2018a; Naumov 2020. 


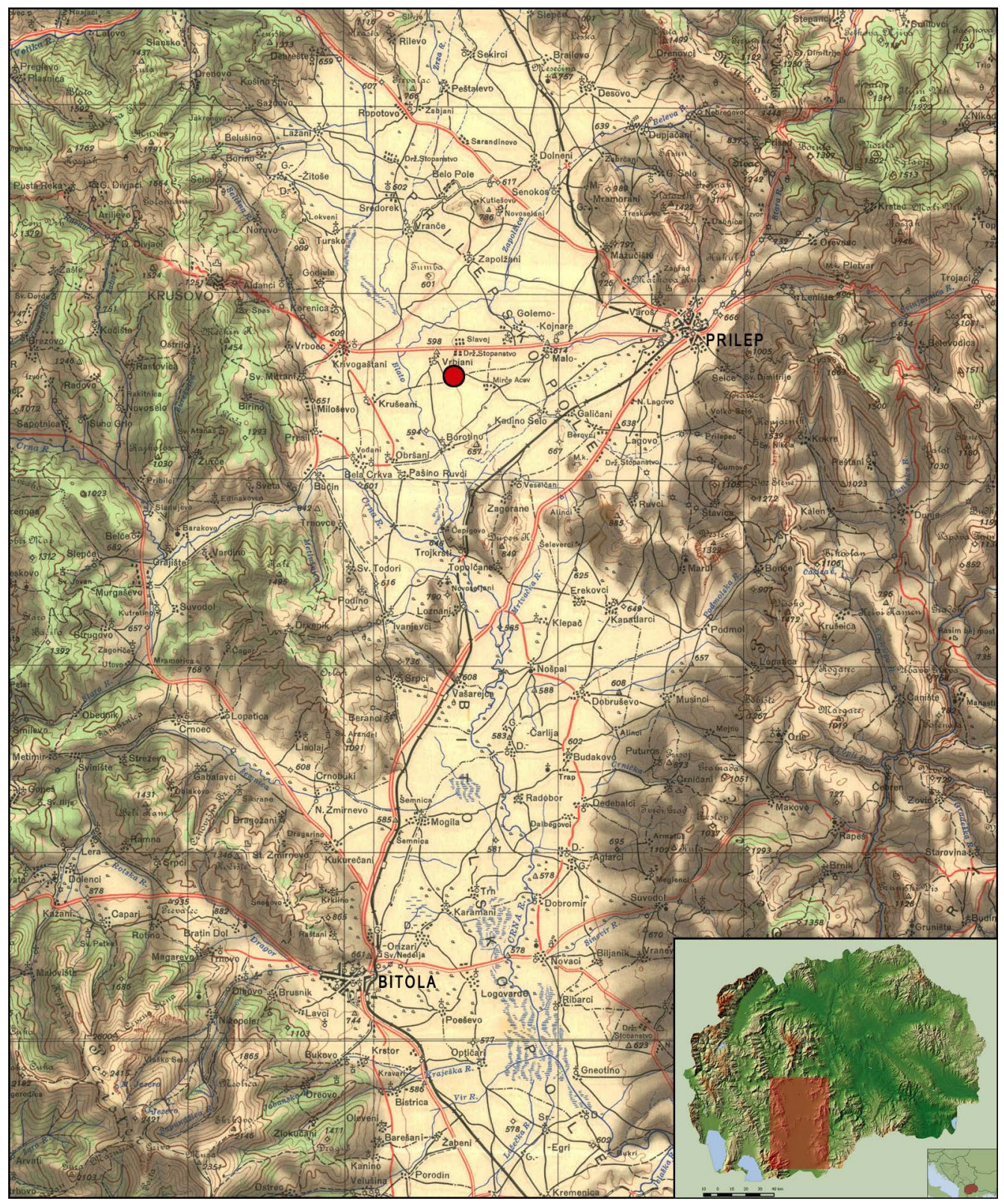

Fig. 1: Map of Pelagonia with indicated position of Vrbjanska Čuka

ern part of Pelagonia (Fig. 1). It was discovered in 1977 and several fieldwork campaigns were initiated in the 1980s, when the central part of the tell was excavated ${ }^{4}$. This led to the discovery of several buildings and constructions, as well as numerous vessels, house models, tablet-altars, figurines and tools common in the Pelagonian Neolithic ${ }^{5}$. After a break of nearly three decades, the excavation of this site continued in 2016 with uninterrupted fieldwork campaigns and laboratory analyses. Each fieldwork season involved

4 Kitanoski et al. 1990.

5 Kitanoski 1989; Mitkoski 2005. the application of new methods of archaeological research in North Macedonia, such as geomagnetic scanning, digital topography of the tell, radiocarbon dating, the study of architectural remains and material culture, 3D modeling of finds and structures, archaeozoological, archaeobotanical, use-wear and lipid analyses, as well as detailed prospection of the surrounding sites ${ }^{6}$. This is a result of joint research in the project lead by the Center for Prehistoric Research in collaboration with the Institute and Museum - 


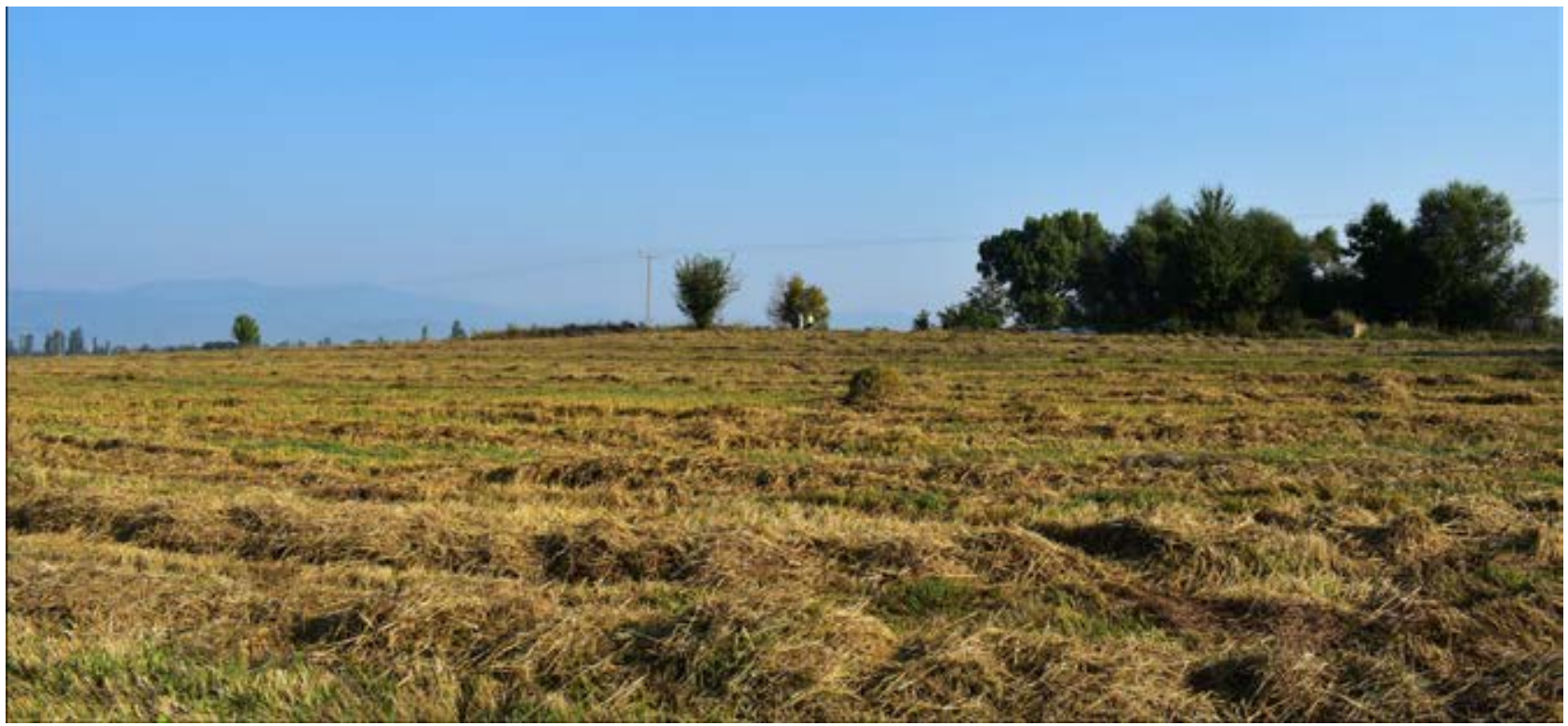

Fig. 2: The Vrbjanska Čuka tell, view from South (Photo: Goce Naumov).

Prilep, Institute of Old Slavic Culture, BioSense Institute, University of Basel, Spanish National Research Council, University of Cologne, University of South Bohemia, University of Bern, University of Primorska, as well as the companies Pryncipat and VR Port. The specialists and students from the project partners contributed to a completely novel insight into the tell, giving a much better understanding of the farming communities who established and lived in this settlement. This paper is therefore comprised of the results obtained from aforementioned research in Vrbjanska Čuka from 2016 until 2020 and place this site more thoroughly within the archaeological map of the Neolithic Balkans.

Vrbjanska Čuka is positioned between Slavej and Vrbjani, $1.3 \mathrm{~km}$ south and southeast respectively from these villages. The site is constituted by a tell in a valley surrounded by the Buševa, Dautica, Babuna, Selečka mountains and Topolnićka Greda hill, and it is close to Crna Reka (the largest river in Pelagonia), whose tributaries are now dried out. It is a tell $3.5 \mathrm{~m}$ high and $180 \mathrm{~m}$ in diameter, elevated above the flatlands, with a few more tells surrounding Vrbjanska Čuka (Fig. 2) ${ }^{7}$. The site's initial settlement was established during the Early Neolithic and, after a huge occupational gap of 6 millennia, it was used as Roman villa rustica with a number of pits in which presumably storage vessels were deposited. A similar economic function was maintained in the Medieval period, with a greater number of pits, but the site was also used as a necropolis where the inhabitants from the surrounding villages were buried. The radiocarbon analysis of samples from the lowest and top levels indicates the earliest and latest periods of site occupation additionally supported by the distinctive Neolithic and Medieval material culture. Currently, the tell is used as an agricultural field, upon which a farm was built in the 1950s and 1970s, and sand was extracted which damaged a large part of the site ${ }^{8}$.

Since 2016, the scope of research was larger than that from the 1980s, mostly due to the extension of the trench, but also because of the larger number of experts and institutions engaged during and after the excavation (Fig. 3). The excavations were initially performed in the same trench from 1980s, but since 2016 have been significantly extended towards the north and west. Apart from the previously researched squares, the fieldwork is focused on the new ones as well, i.e. quadrants from 16 to 32 (except 20). These quadrants are $5 \times 5 \mathrm{~m}$ large, thus the current trench now measures $20 \times 20 \mathrm{~m}$. In some of the squares, the lowest layers were reached and the presence of several buildings was recorded.

During the excavation, the discovered features were documented with the Harris Matrix system which enabled a comprehensive log of all features and their documentation through stratigraphic units (SU). A dozen daub buildings with interior structures were discovered during the excavation of the few Neolithic horizons, but also numerous artifacts were discovered, which provided insight into the economic, social and symbolical spheres of farmers 


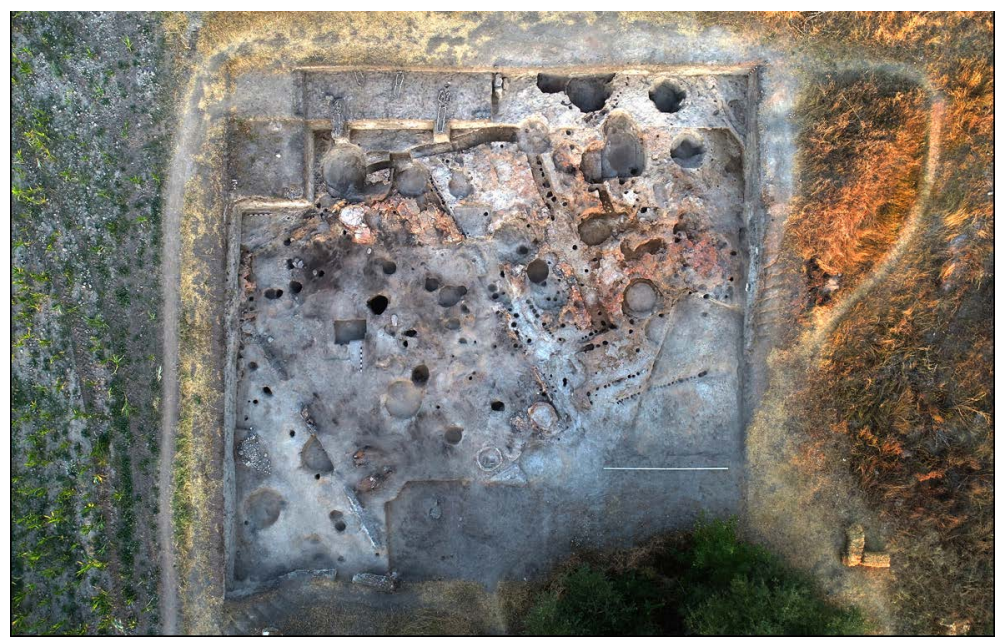

Fig. 3: Aerial image of the trench in the center of the tell (Drone photo: Hristijan Talevski). who established this settlement and lived there during the $6^{\text {th }}$ millennium BC. Detailed excavation and documentation provided thorough insight into the stratigraphy of the site and its complexity in formative processes of various cultural horizons. Therefore, this paper will focus only on the Neolithic period determined in Vrbjanska Čuka with an emphasis on the natural, social, economic and symbolic processes detected by the study of layers, material and architecture, as well as by a variety of analyses performed in different laboratories.

\section{Geological features of the site and the surrounding region}

The Neolithic settlement of Vrbjanska Čuka was established upon eluvial and eolian deposits, which represent the uppermost soil levels of the Pelagonian valley. This valley is a tectonic depression created by young (neotectonic) rifts mainly with a North-South disposition. The depression was created in the end of the Middle Miocene and was gradually transformed into a widespread freshwater lake in which Miocene, Pliocene and Lower Pleistocene layers were deposited. The changes of tectonic conditions of the Mediterranean Sea and its deepening during the Pliocene and Lower Pleistocene initiated the creation of a new river network with larger rivers in the fields of Macedonia. Along these rivers, the outflow of the waters from Macedonian lakes towards the Aegean Sea also started through the Vardar river, a major water assembly artery created 1-0.85. Ma ago'. In the same period, the valley of Crna Reka was formed where the waters from Pelagonian

9 Arsovski 1991.
Lake gradually started to outflow to the Vardar River and the Aegean Sea until its definite drainage.

Afterwards, the period of intensive erosion of Pliocene sediments started, as well as several processes of decomposition of eluvial sediments, covering the valley's peripheral parts with gravel, sandy and clayish material from torrential waters, which commenced the formation of new river network. All these processes contributed to the deposition of fertile soil in the larger part of Pelagonia and to the creation of wetland areas before and during the Neolithic period. Some of them are preserved even nowadays along the riverbed of the Crna Reka, while others are covered with a relatively thin layer of soil.

In the period between 1974 and 1977, there were deep drillings in the vicinity of Vrbjanska Čuka and its wider area focused on layers with coal and potable water. Such drillings were performed in the villages of Slavej, Vrbjani, Malo Konjari, Krušeani, Borotino and others from the surrounding area of the archaeological site. The description of the cores points to several layers of clay, sand and gravel under the recent horizon which do not have features of wetland sediments (Tab. 1). Only the core D-10 extracted in the vicinity of Veselčani village, $7 \mathrm{~km}$ southeast from Vrbjanska Čuka, recorded sediments indicative of wetlands. This core of $52 \mathrm{~m}$ depth records the following deposited features:

Tab.1: List of determined deposits in one of the cores in Prilepsko Pole.

\begin{tabular}{ll}
\hline Height & Sediments \\
\hline $0,0-0,80 \mathrm{M}$ & humus \\
$0,80-3,90 \mathrm{M}$ & black clayish material with wetland origin \\
$3,90-5,80 \mathrm{M}$ & gravel-sandy proluvial material \\
$5,80-27,00 \mathrm{M}$ & sands with different colors \\
$27,00-44,50 \mathrm{M}$ & sandy clays and clays with different colors \\
$44,00-52,00 \mathrm{M}$ & paleorelief of mikashists \\
\hline
\end{tabular}


According to the provided data, the sediments with black clayish material created above the wetlands are right under the humus layer, while the core D-10 could refer to the periphery of the marshes. The morphology of the terrain indicates possible disposition of the wetland from Vrbjani towards Veselčani so that the water flowed out towards the south. Nevertheless, in order to confirm the outlines of this wetland and its features, new geological surveys with several cores are necessary to be performed in the future.

\section{Topographic measurement and digital elevation model of the tell}

During the excavations of Vrbjanska Čuka, the topographic measurements were also conducted and digital elevation models for the tell were generated, enabling an accurate determination of the shape, volume and height of the tell, and also of its modifications resulting from the constant use of this location. Given that the site is partially damaged from the foundations of a 1950s farm, sand extraction activities, modern plowing and changes to its shape due to the vegetation, the application of geodetic measurements and modeling yielded a consistent picture of the site's look and size.

The limited visibility of the tell is due to the vegetation (high reeds and trees), but also due to the site's topography which, as the majority of Pelagonian tells, rises only slightly above the plain. Because of that, by utilizing GPS and RTK devices, a grid network of points was placed on the entire surface of the tell. A total of 172 points with an equidistance of 10 and 20 meters were recorded, including points where the surface suggested a slight decline, so the final model would be improved (Fig. 4). The measurements show that the highest point of the tell is 603.187 meters, and the lowest is 599.67 meters, while its NorthSouth diagonal length is approximately 180 meters. The West-East diagonal length based on the visual profiles of the tell shows a much larger diameter (approximately 280 meters). Nevertheless, this value is a result of the damaged edges in this part of the tell and should not be used as a reference until further, more precise measurements have been taken. The points were then transformed in the MGI Balkan Zone 7 system and, with the application of the TIN method for interpolation, a digital elevation model was generated. The created elevation model containing height values contributed an accurate representation of the tell's outline, including its shape, height, volume and also the variations in its periphery, taking into consideration the possible ditch that surrounded the Neolithic settlement.
Apart from this outcome, the GIS modeling provides the possibility for 3D visualization of the tell and virtual documentation of the state in which the tell is today.

The construction of DEM is an important part in the research and documentation of an archaeological site ${ }^{10}$. The elevation layer for Vrbjanska Čuka was produced based on individual points and their respective heights, whereas the possibility for producing DEM based on digitalization of contour lines from topographic maps was excluded from the very beginning. The reason behind this decision are the topographic features of Pelagonian tells concerning their height ${ }^{11}$. The average height of these archaeological sites is between 2 and 4 meters and in order to digitalize and generate elevation models, the research requires specific topographic maps with a high spatial grid resolution which were not available. The choice of the type of interpolation was also affected by the method of gathering the spatial data. During the parameter selection process, the TIN (Triangulated Irregular Network) method was selected, which was suitable for the production of the elevation model, because the field data that was processed in GIS and the grid of points were irregularly deployed within space $^{12}$. The excavated area in the central part of the tell (trench) was transformed into a virtual flat surface with the positioning of additional points around the trench with the dimensions $20 \times 20 \mathrm{~m}$, also in order to position the newly made UAV (drone) imagery on this area.

\section{Geomagnetic scanning}

After the site excavation, the process of geomagnetic surveying of Vrbjanska Čuka and several neighboring tells started. Magnetic measurements were made with Fluxgate magnetometer 4.032 DLG Foerster Ferrex, equipped with two sensors with resolution of $0,2 \mathrm{nT}$ that measures the degree of vertical component of the Earth's magnetic field. The data was collected in two-way format (10 measurements were taken in one square meter). A large number of anomalies from various characters were processed and mapped in Terra Surveyour.

This method was previously applied during the research on prehistoric tells in Pelagonia, and because of its exceptional results it was used in the archaeological fieldwork associated with this site and its surrounding tells ${ }^{13}$.

10 Westcott/Brandon 2000

11 Naumov et al. 2014.

12 Wheatley/Gillings 2002.

13 Naumov et al. 2014; Naumov et al. 2017b; Naumov 2020. 


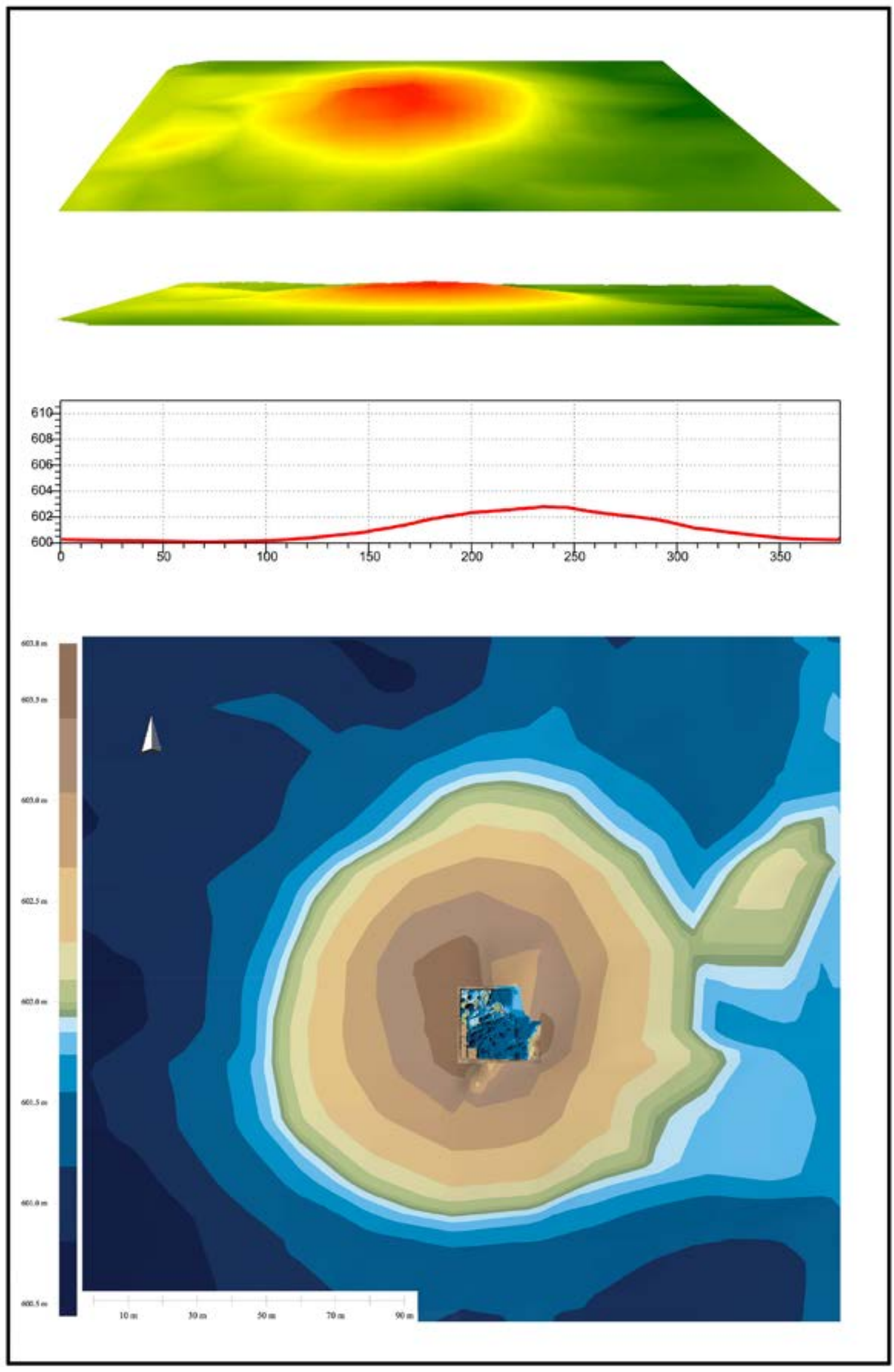

Fig. 4: Digital Elevation Model and visual section of the tell (Illustrations: Gjore Milevski and Hristijan Talevski). 


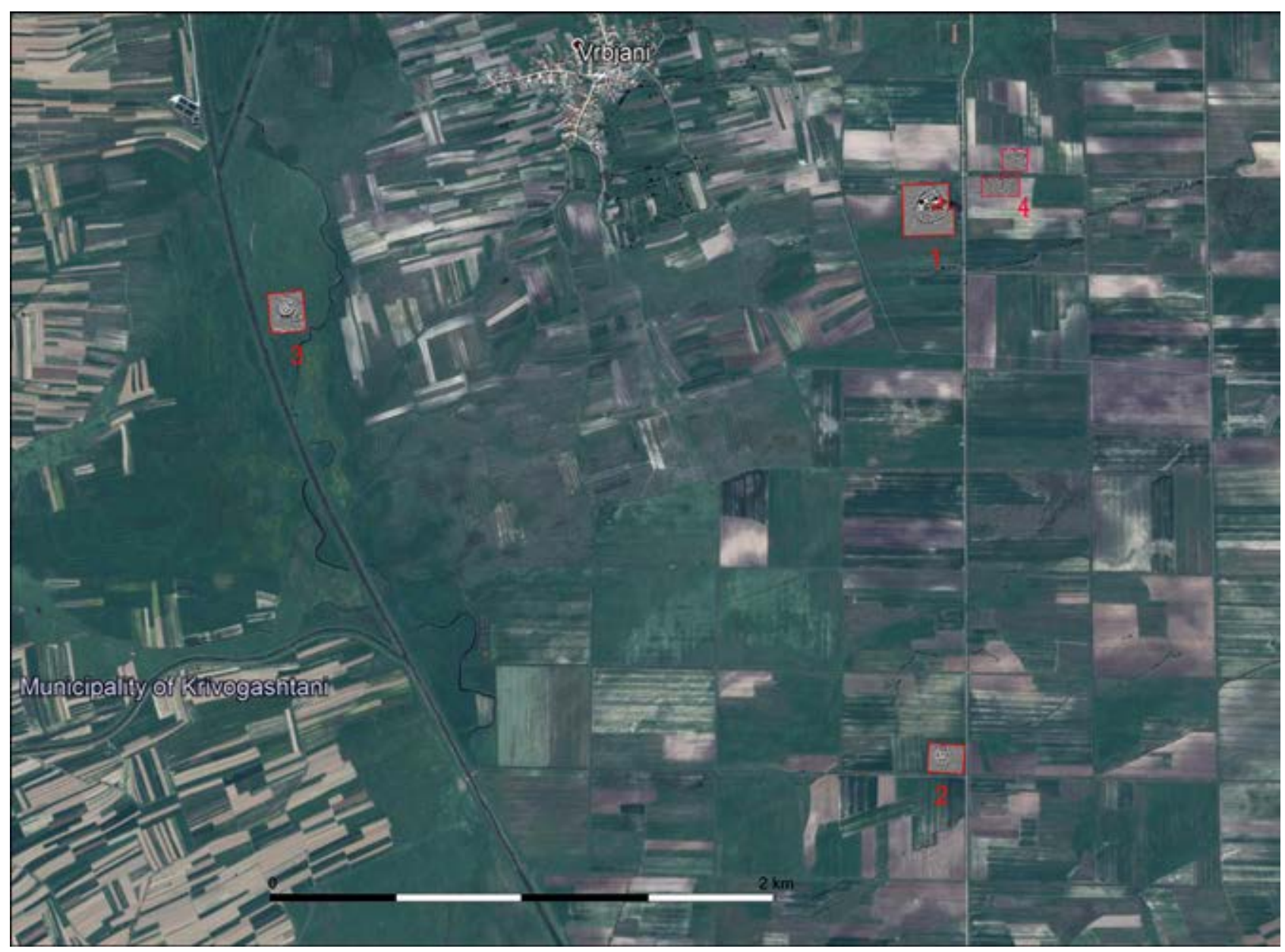

Fig. 5: Map of the tells where the geomagnetic survey was performed: 1. Vrbjanska Čuka-Slavej; 2. Tumba-Borotino; 3. Krušeanska Čuka-Vrbjani; 4. Konjarski Vis-Slavej (Illustration: Marcin Przybyła).

In appropriate conditions, clear anomalies are created from the remains of buildings made of daub and in rare cases from those made of stone. Human activity increases the sensitivity of the upper layer of the soil, which causes the phenomenon manifested as "zonal" magnetic anomalies $^{14}$. As a result, the magnetic method allows almost complete recognition of archaeological sites and prehistoric ones in particular. Nevertheless, the main drawback is the small depth of penetration, rarely surpassing more than 1-1.5 meters ${ }^{15}$. The survey provided a completely new knowledge for Vrbjanska Čuka consisting of dozens of buildings enclosed by a ditch, but also provided an insight into the spatial organization of the tells neighboring this site (Fig. 5) ${ }^{16}$.

14 Misiewicz 2006.

15 David et al. 2008.

16 Naumov et al. 2018a.
The geomagnetic research of this site included a total area of 3.6 hectares, partially transformed in modern times. The presence of high voltage pylons and remnants of farm foundations caused numerous disturbances, which affected the readability of the results. Apart from that, several anomalies related to the Neolithic tell were discovered. The results are shown in the form of magnetic maps in grayscale (Fig. 6a). The interpretation of these particular anomalies indicates the following characteristics: a linear positive anomaly associated with a defensive ditch (with two hypothetical entrances (Fig. 6b, 10); a linear positive anomaly associated with a smaller ditch or a communication line (e. g. path, Fig. 6b, 11); a group of dipolar anomalies associated with remains of burned clay from the buildings (Fig. 6b, 12-30); two groups of dipolar anomalies forming a square structure in the central part of the site (may be related to the building of the Roman period (Fig. 6b, 31-32); a group of positive anomalies connected to the remains of buildings outside of the tell (Fig. 6b, 33); a linear positive 


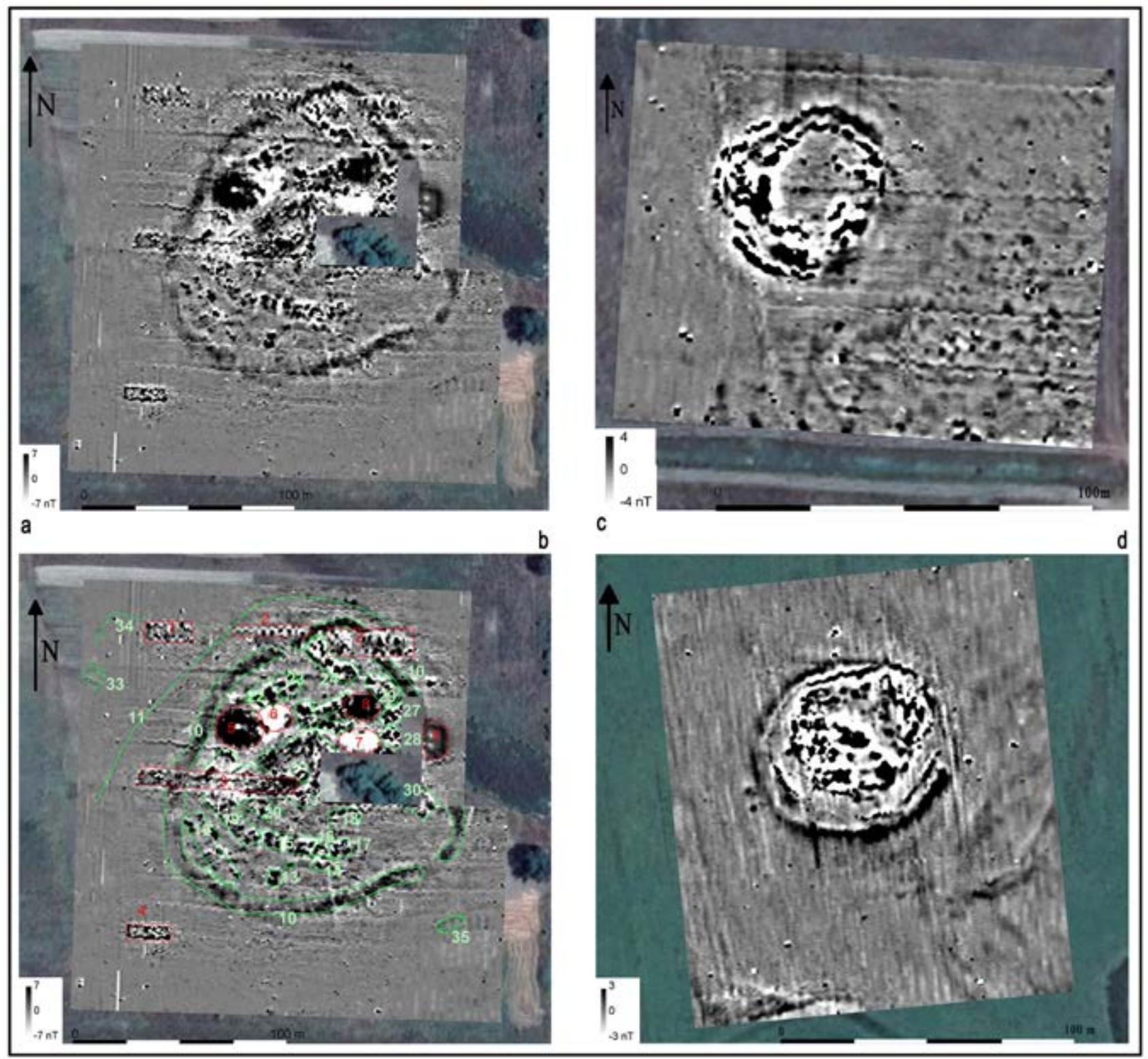

Fig. 6: Results from the geomagnetic survey: a/b. Vrbjanska Čuka; c. Tumba-Borotino; d. Krušeanska Čuka (Illustrations: Marcin Przybyła).

anomaly most likely associated with 'Building number 33' (Fig. 6b, 34); and a probable group of positive anomalies associated with remains of a building (Fig. 6b, 35).

As mentioned above, besides Vrbjanska Čuka, the neighboring tells were part of the geomagnetic scanning, such as Konjarski Vis, Borotino and Krušeanska Čuka (Fig. 5). The reconnaissance of Konjarski Vis indicates a surface material synchronous to Vrbjanska Čuka and some belonging to later prehistoric periods, but geomagnetic data provides information for entirely different architectural features and spatial organization ${ }^{17}$. Tumba-Borotino

17 Ibid. 128; Naumov et al. 2017b, 16. surface survey records the presence of Late Neolithic and Chalcolithic vessels and figurines, while the scans demonstrate a site with several concentric ditches on one side of tell, as well as entirely different features on the other side of it, most likely burials (Fig. 6c) ${ }^{18}$. Krušeanska Čuka is a Chalcolithic tell excavated in the 1980s and surveyed in $2017^{19}$. The geomagnetic research indicates that there is a small, fortified settlement of circular shape (approximately $70 \mathrm{~m}$ in diameter) consisting of defensive ditches full of burned material, burned walls or palisades, buildings and

18 Ibid. 129.

19 Temelkoski 1999; Naumov et al. 2017b, 14. 
pits (Fig. 6d). In sum, the reconnaissance and scanning confirm the presence of Neolithic and Chalcolithic tells not far from Vrjbjanska Čuka, but in a way different regarding the spatial organization. Future excavation of these sites could provide more information on the social structure of communities that established them, but also the similarity or diversity of architectural features with those in Vrbjanska Čuka.

\section{Stratigraphy of Vrbjanska Čuka}

By using the Harris Matrix system, a very detailed stratigraphy overview of the settlement was made by defining all archaeological features referred to as stratigraphic units. Thus, a significant number of layers were recorded in the Neolithic horizons, but also new features in the Classical and Medieval horizons. Following the stratigraphy from the most recent down to the oldest layers, certain interpretations can be suggested. There are Medieval and Classical horizons that are difficult to separate, as well as three Neolithic ones primarily defined by the architectural features and their layers (Fig. 7). The features of the Neolithic horizons will be more thoroughly presented here through architecture and finds, whereas the detailed overview of later horizons and its material culture has been provided in the previous publications ${ }^{20}$.

Contrary to the interpretations from the 1980 s research concluding that the Neolithic settlement was single-layered ${ }^{21}$, a detailed observation of the sections and features within the trench proved otherwise, as there are three Neolithic horizons that are the outcome of continuous settlement occupation during the first half of $6^{\text {th }}$ millennium $\mathrm{BC}^{22}$. The new excavation results indicate that the initial settlement was established atop a smaller, natural elevation composed of a thick sand deposit originating from a Neogene lake ${ }^{23}$. On top of these deposits, multiple daub buildings were subsequently built, destroyed and rebuilt over a period of ca. 300 years, according to available radiocarbon dates. As a result, $1.10 \mathrm{~m}$ of Early Neolithic deposits have been accumulated and at least 6 building phases have been identified without indicative natural interruptions. The building phases mentioned above are tentatively grouped into three Neolithic horizons, nomi-

20 Mitkoski 2005; Temelkoski/Mitkoski 2005; Naumov et al. 2018a; Naumov et al. 2018b.

21 Kitanoski 1989; Kitanoski et al. 1990.

22 Naumov et al. 2018b; Naumov et al. in press.

23 Arsovski 1997; Dumurdzanov et al. 2004. nally determined according to the architectural features, as detailed analysis of material from each level is not yet finalized (Fig. 7).

The latest Neolithic horizon (III) lies just beneath the Classical layer, with architectural remains and pits from the Roman period clearly separated by the soil structure. The soil is gray and particularly compact, significantly different from the one above. Such compactness could be due to the long exposure of the horizon to weather conditions and its usage as a surface for new activities 6,000 years later. It is evident that burning took place in this horizon, hence its gray soil could partly derive from the ashes; however, this could also be due to various climate processes occurring over the past 6 millennia, during which there were no settlers on the tell. Material found in this horizon does not significantly differ from the one in the Early Neolithic horizons, therefore the Late Neolithic phase of the settlement cannot be assumed. Numerous grinding stones, foundations and posts from Buildings 6, 8,12 and 14 have been found there, so it is evident that the settlement was active in this period in terms of everyday life and cereal processing. Given its exposure, this horizon, as those below it, were considerably damaged by Late Classical and Medieval activities, i. e. the digging of larger pits. Therefore, apart from the Neolithic material, there were pottery fragments, terracotta building materials, human and animal skeletal remains inside the fill of these pits used in these later stages of the archaeological site.

Although significantly smaller in terms of stratigraphic features and height, the next horizon (II) is different. All constructed features detected within it consisted of burnt daub, which is atypical for the horizon above. Buildings 4 and 15 were associated with this horizon that also contains large amounts of ceramic and lithic finds, among which include elements similar to those in the upper Neolithic horizon (III). Several layers have been determined in this horizon, consisting of thick burnt daub walls and plaster, referring to an intense period of activity within the settlement. They are a result of relatively frequent activities in Buildings 7 and 10 and their collapsed walls made of unburnt daub.

The oldest horizon (I) was positioned right above the natural geological formations, i. e. the sand of the Neogene Lake in Pelagonia. Two levels of buildings were identified there, consisting of 6 layers of daub, plaster and soot, i.e. the architectural deposits associated with Buildings 1 and 2 (with burnt daub) and Buildings 5, 7 and 10 (with smaller and bigger posts and unburnt daub). A massive Neolithic pit was recorded south of Building 2, but also a larger pile of stones and broken grinders next to it, which were deliberately piled up in this area. Similar to the upper ho- 


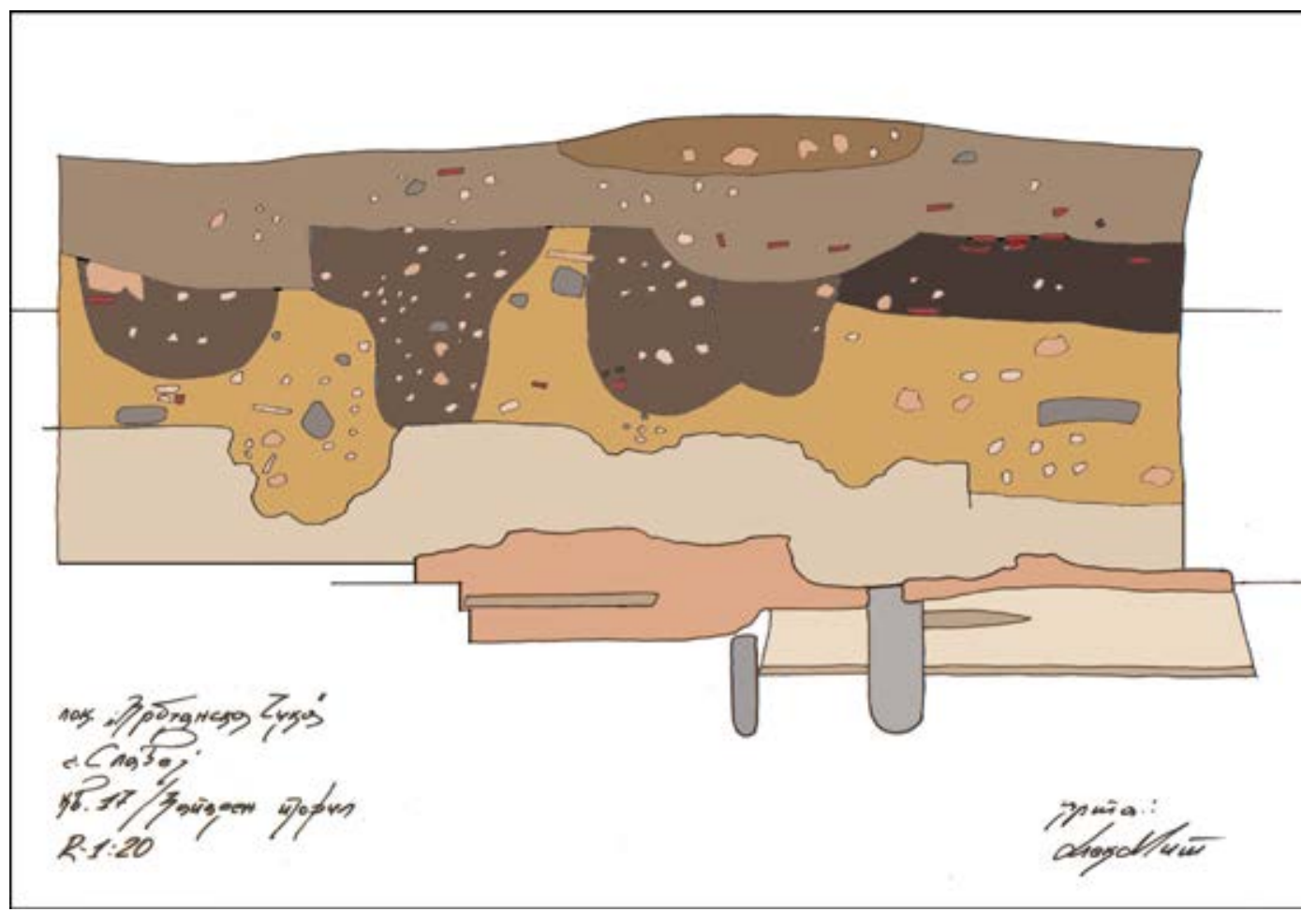

Fig. 7: Western profile of the quadrant 17 in the excavated trench (Drawing: Aleksandar Mitkoski; Editing: Goce Naumov).

rizons, a part of this space was damaged in 1970s during extraction of sand with a bulldozer, so a direct insight into the deposits over the substratum, i. e. the sand, is not possible. White-painted pottery with distinctive decoration common for Early Neolithic in Pelagonia was found within this horizon. Its Early Neolithic date is further confirmed by the radiocarbon analyses of wheat seeds documented in Building 2, giving a range between 6000 and 5900 BC. The dating of more samples from Vrbjanska Čuka is underway, which will provide a better understanding of the chronology of the initial and subsequent phases of this settlement.

\section{Dating of the Neolithic layers}

One of the aims of the Vrbjanska Čuka research is the exact dating and its application within the already determined chronological frame of the Balkan Neolithic. With this in mind, multiple samples were taken from different contexts and horizons (charcoal, seeds and vessel fragments containing lipids suitable for dating) in order to obtain a thorough chronological sequence and temporal framework for the establishment of the Neolithic settlement up to its abandonment. Several types of samples from Vrbjanska
Čuka were sent to various laboratories for radiocarbon dating in order to obtain an accurate chronology of the site. Consequently, a set of dates was provided that give the initial chronological framework of the settlement between 6000 and 5700 BC, i.e. the end of Early Neolithic in terms of Balkan chronology (Fig. 8) ${ }^{24}$. Many more samples were taken from each level determined in the stratigraphy of the site that will soon be dated as well, so a solid temporal sequence and Bayesian modeling of the duration of each horizon and therefore a firm basis for the interpretation of the settlement's beginning and end will be produced.

For the first group of dates from Vrbjanska Čuka, nine samples were sent to the National Center of Accelerators at University of Seville (Spain), Laboratory for the Analysis of Radiocarbon with AMS at the University of Bern (Switzerland) and the Organic Geochemistry Unit/BRAMS at the University of Bristol (United Kingdom). Radioactive carbon isotopes $\left({ }^{14} \mathrm{C}\right)$ were measured in order to determine the latest period of activity of organic samples. The majority of samples were cereal and pea remains sampled from the floor in Building 2 (Horizon I), considered as one of the earliest Neolithic contexts. There were few from the upper-

24 Naumov et al. 2018b; Stojanovski et al. 2020a; Naumov et al. in press. 
most Neolithic layers (seed and lipid from pottery), as well as from the final stages of the tell (human teeth and seed).

The earliest date comes from the seed sample CNA4704, it is determined at $7036 \mathrm{BP}$ with a standard deviation of \pm 36 years while its calibration gives a time span between 5996 and 5844 CalBC with $95.4 \%$ probability $^{25}$. Nevertheless, although its temporal range is smaller than that of the previous sample, its peak still indicates the date of $5975 \mathrm{BC} \pm 36$ years. The next date, associated with the CNA-4703, is determined at 7030 BP with a standard deviation of \pm 37 years. The calibration of this date gives the range between 5999 and 5840 CalBC with $95.4 \%$ probability and chronological peak around 5970 CalBC \pm 37 years. The third earliest date comes from the sample BE-8236, dated at 6995 BP with a standard deviation of \pm 24 years. Calibration of this date indicates calendar dates from 5981 to 5807 CalBC with a $95.4 \%$ probability. The chronological peak of the chart suggests $5890 \mathrm{BC}$ as a probable year, as well as one another smaller peak referring to $5960 \mathrm{BC} \pm 24$ years.

The sample CNA-4705 has a lab rate of $6976 \mathrm{BP} \pm 36$ years that is earlier than the previous sample, but its peak indicates a somewhat later date. Calibration of this sample provided two chronological frames with the one that has 95.4\% probability spanning from 5978 to 5947 CalBC. Due to two calendar ranges, its peak indicates the dates of 5960 and $5880 \mathrm{BC} \pm 36$ years. The next sample BE-8235 has a lab value of $6946 \mathrm{BP}$, with a standard deviation of \pm 44 years. This value has a calendar date between 5972 and 5732 CalBC with $95.4 \%$ probability. According to these dates and the two chronological peaks in the chart, the analyzed seed could be dated around 5960 and $5820 \mathrm{BC} \pm 44$ years.

It should be noted that all five aforementioned samples are from Building 2 with an earliest date of around 5975 CalBC and the latest approximately 5960 or 5820 CalBC. If such dates are considered, then a household activity of 10 or 100 to 150 years in this building can be proposed. Once the Building 2 is dated, it would be possible to constrain this chronological range with the use of Bayesian modeling. Currently, the first peak of latest dates indicate activity of about 10 years in Building 2 , although a longer usage of this architectural unit could be expected. On the other hand, the second peak of the same calibration point to approximately 100 years of its employment, but it is uncommon for daub buildings to be used over such a long period. Nevertheless, this building

25 Calibration was done in the OxCal 4.3 program from the Oxford Radiocarbon Acceleration Unit (Bronk Ramsey et al. 2013). For a more thorough review of dating processes and calibration of lab dates within Pelagonian and Balkan chronology see Naumov 2016b. has remarkably massive walls, a number of internal daub structures, traces of renewal and big posts associated to it evidently demonstrates an intended durable workshop or house. The neighboring Building 11, as well as Building 7 and 10 above it actually reflect two phases contemporary to the use of Building 2 (see a more detailed discussion below), which already suggests that this building could have been used over a longer time than usual.

Apart from these samples, two more were taken from some of the latest layers of the Neolithic settlement at Vrbjanska Čuka. One of these samples belongs to the uppermost Neolithic horizon and it is associated with lipid remains in a shard (BRAMS 2838) ${ }^{26}$. It has a date of $6839 \mathrm{BP}$ and standard deviation of \pm 47 years. The calibration provides a combined probability with one of $95.4 \%$ sigma range that has a temporal range between 5813 and 5640 calBC. Hence, its peak indicates the date of $5725 \pm 47$ years. The sample CNA 4705 is a pea seed and it was found in a small channel dug for the foundations of the Building 14, one of the last in the stratigraphy of the Neolithic settlement. Its deep foundations were cut through several buildings below, even reaching the Building 2. It was dated at $6824 \mathrm{BP}$ with a standard deviation of \pm 35 years and calibrated chronological span between 5762 and 5640 calBC. The peak of this calibration indicates the date of $5720 \mathrm{BC} \pm 35$ years and makes it the most recent Neolithic dating of Vrbjanska Čuka so far.

According to these dates the approximate end of the Neolithic settlement could be estimated to have taken place around $5700 \mathrm{BC}$, although the samples from the few uppermost, thinner layers should be taken in order to have a more accurate determination of the final stages. In regard to the final stages of the tell itself, there are also two more dates that can contribute, but go beyond Neolithic chronology. The sample NVČC 14 indicates the years between 907 and 1119 AD, i.e. the Middle Ages, and the sample BE-8237 has the chronological range between 1959 and $1986 \mathrm{AD}$, corresponding to the time when the top of the tell was used as a farm, later for sand exploitation and finally as an excavation area.

Nevertheless, at least seven samples provide excellent information for the initial dating of the beginning and end of the Neolithic settlement. Considering the date accuracy of samples and the possible chronological extent, Horizon I of Vrbjanska Čuka can be dated around 6000 BC and Horizon III approximately at 5700 BC (Fig. 8). This refers at least to Building 2 (one of the earliest) and Building 14 (one of the latest). According to the established

26 Stojanovski et al. 2020a. 


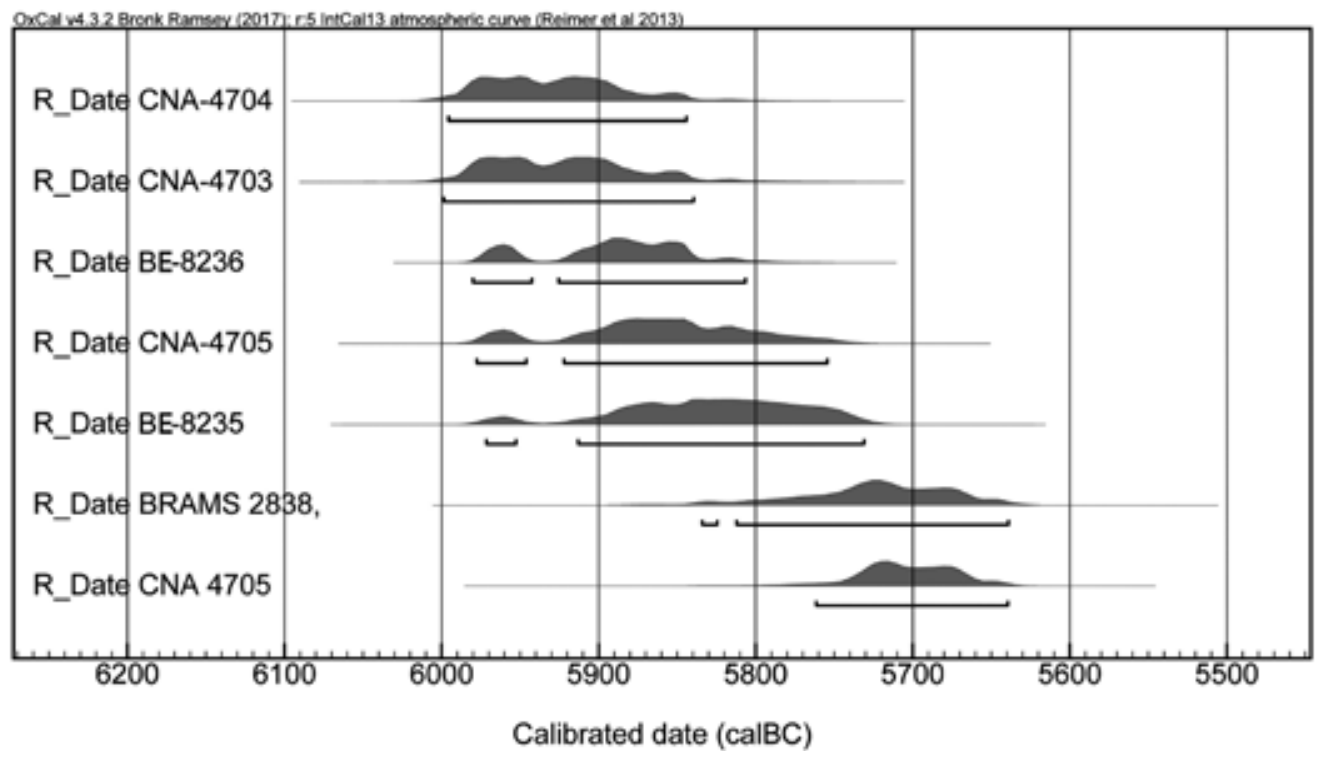

Fig. 8: Chronological sequence of the dates from Vrbjanska Čuka (Calibration: Goce Naumov).

chronological frames of the Balkan Neolithic ${ }^{27}$, these dates places the establishment of the settlement during the end of the Early Neolithic. This is not surprising, as similar chronological ranges were obtained for multiple Neolithic sites in Pelagonia ${ }^{28}$. According to the calibration of data from radiocarbon analyses in the 1970s at labs in Austin and Zagreb, and in 2010s at labs in Seville, Bristol and Bern, many of the Neolithic settlements in Pelagonia were established and mainly active in the period corresponding to span of Vrbjanska Čuka, i. e. during first 300 years of $6^{\text {th }}$ millennium $\mathrm{BC}^{29}$.

\section{Neolithic Buildings}

As previously mentioned, 17 Neolithic buildings were recorded during the Vrbjanska Čuka excavations although few could belong to a single domestic unit. Given that multiple structures with evidently distinct features and potential functionalities were discovered, the team decided to name them as buildings instead of the previously used terms houses or sanctuaries. For the moment, only Buildings 1 and 2 are completely excavated and a discussion concerning these features will be provided below, while the remaining buildings will be discussed only in terms of architectonic character as they are damaged or not completely excavated.

27 Reingruber/Thissen 2016.

28 Naumov 2016a; Naumov 2020.

29 Srdoć et al. 1977; Valastro et al. 1977; Pazdur 1990; Naumov 2016b.
Building 1 was excavated in the 1980s and interpreted as a sanctuary based on its interior structure, referred to as an altar (Fig. 9) ${ }^{30}$. However, a reconsideration of the architectural features and their comparison with other buildings found on the site during the recent archaeological campaigns requires a more cautious interpretation of Building 1. The so-called altar could have served as a massive granary consisting of a system of lateral bins for storing and processing cereals (Fig. 20). This four-meterlong daub structure indeed has stair-like applications on the walls commonly featured in the small tablet-altars, but its use could be explained in terms of agricultural economy with an outlook that embodies the symbolic protection of groceries that were stored and processed inside ${ }^{31}$. Therefore, due to the absence of evidence for the ritual activities, Building 1 cannot be considered as a sanctuary, but rather a dwelling or a workshop where cereals were stored and processed for consumption. In the forthcoming field seasons, this observation will be reexamined by re-excavating what is left on site from this building, although the remaining evidence may also not be conclusive.

Building 2 also requires particular attention due to its specific features and size (Fig. 10). Similar to Building 1, it belongs to Horizon I and, so far, it is the earliest building on the site established right above the natural deposit of sand. Although it was significantly damaged by the Roman and Medieval pits and partially by sand extraction, the majority of its daub structures were still preserved. This

30 Kitanoski et al. 1990; Mitkoski 2005.

31 Mitkoski/Naumov 2007. 


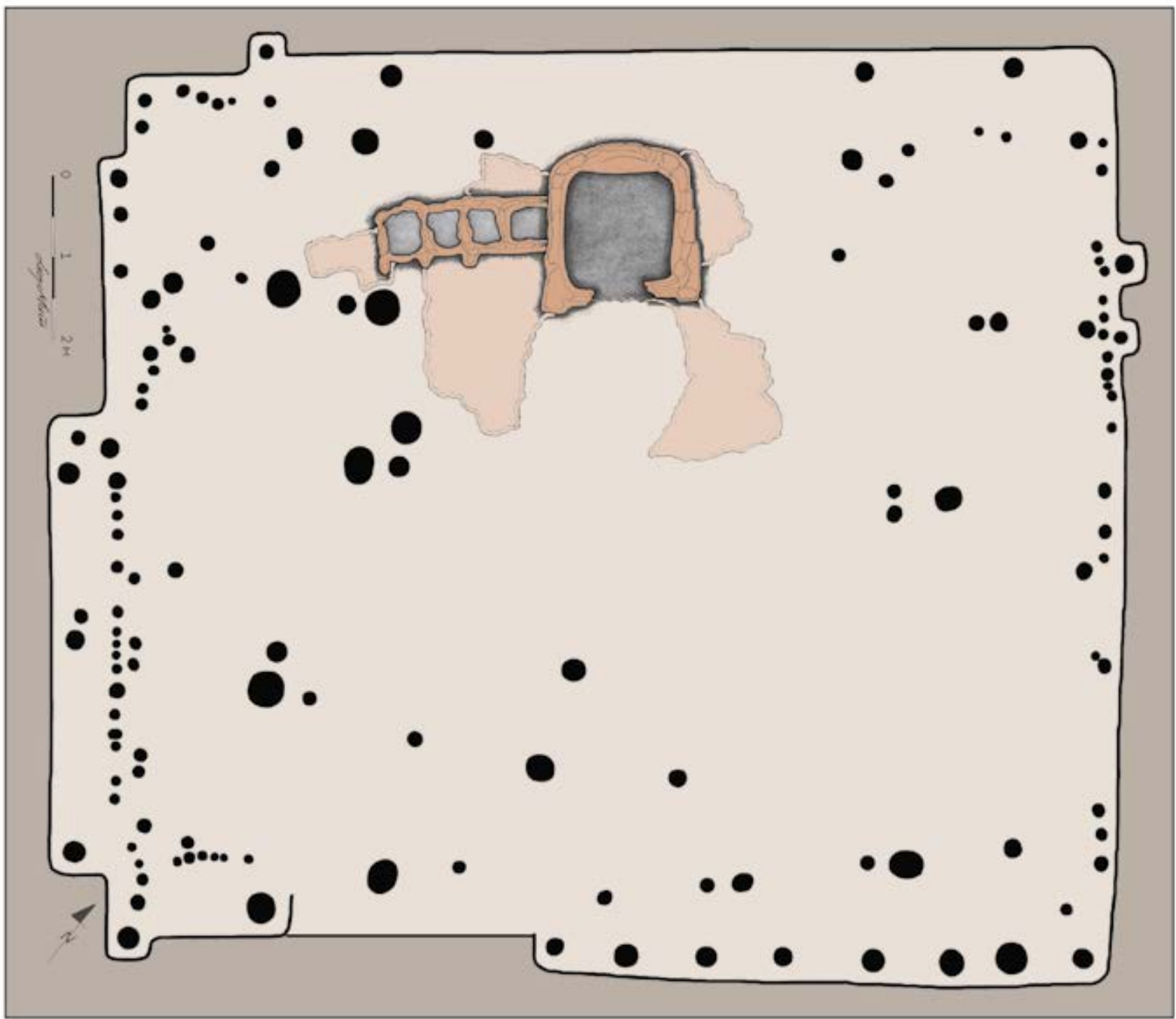

Fig. 9: Plan of the Building 1 with the large granary and lateral bins (Drawing: Aleksandar Mitkoski; Editing: Goce Naumov).

massive $130 \mathrm{~m}^{2}$ building was made of thick, burned daub walls, three large posts in the middle and contains 11 clay structures including three ovens, two bins, one platform and three round plastered working areas for processing cereals, as well as approximately 30 grinding stones turned upside down (Fig. 11; 19). On its western side there are remains of a second storage with a bin which most likely fell on the oven and plastered working areas in this part of the building.

Building 2 is the largest Neolithic building in Macedonia discovered so far, also remarkable is the great number of clay structures which most likely demonstrates its function as a workshop for the processing of cereals or larger domestic unit. A quantity of wheat seeds and chaff sampled for archaeobotanical analysis and the grinding stones further corroborate such function although its role as a dwelling should not be disregarded either. There were no complete or restorable vessels and the number of pottery shards, figurines and tools is very small; which is indicative for cleaning of the building after the last stages of occupation. Such cleaning activities, the placement the grinding stones upside down and the intentional firing of the daub walls indicates a symbolic action of building abandonment which was also practiced at other Neolithic sites in the Balkans ${ }^{32}$.

Building 3 was excavated in the 1980s and, unfortunately, there is no adequate information on its strati-

32 Gheorghiu 2007; Fidanoski 2015. 


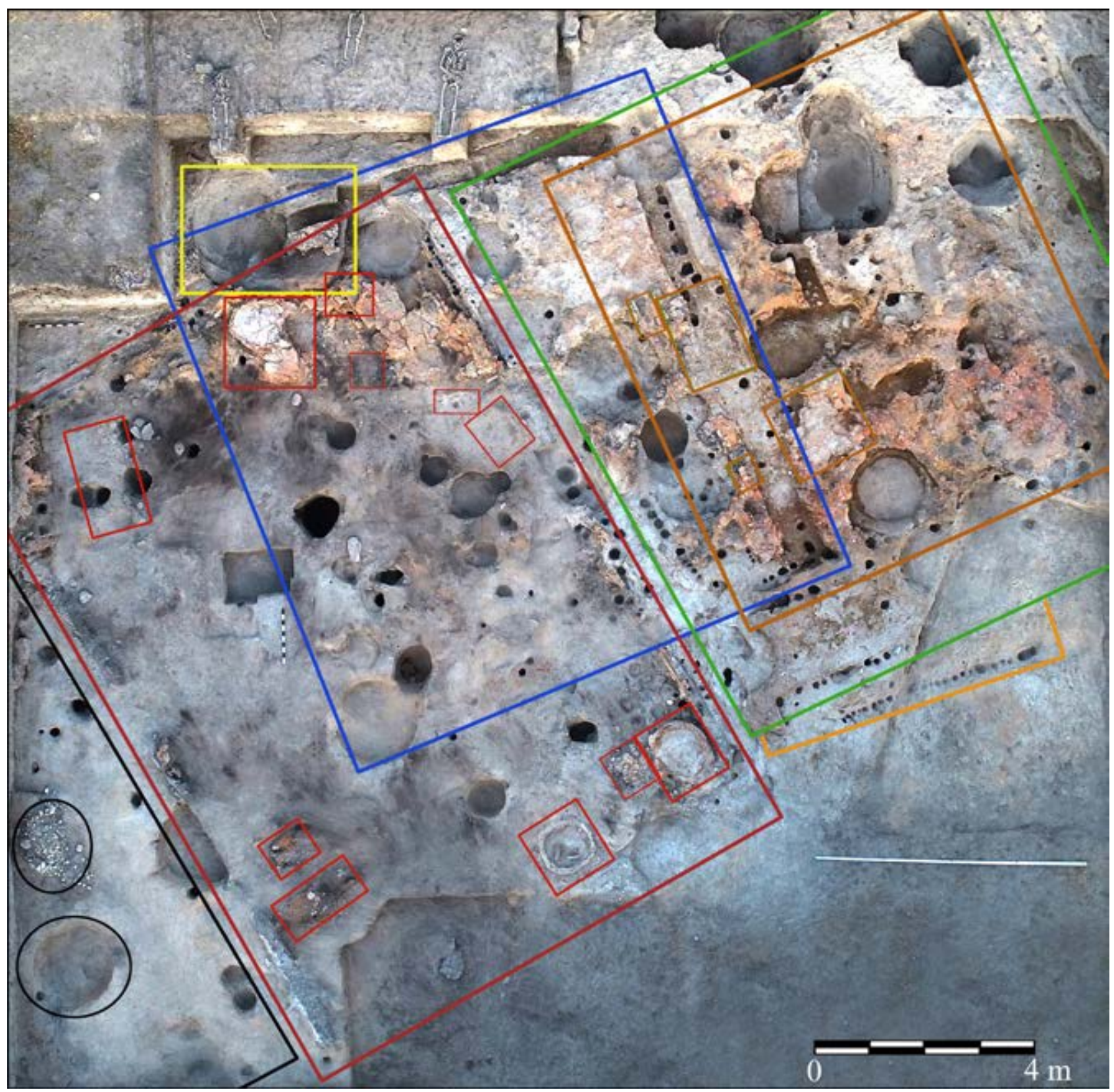

Fig. 10: Disposition of several Neolithic buildings outlined in color and with indicated interior daub structures (ovens, bins, grinding areas) in some of them: Building 2 (red), Building 4 (brown) Building 5 (black), Building 6 (green), Building 11 (orange), Building 14 (blue), pit-dwelling? (yellow) (Photo: Hristijan Talevski; Editing: Goce Naumov).

graphic position and the interior layout ${ }^{33}$. Building 4 belongs to Horizon II and was discovered during the current fieldwork. It is consisted of massive daub walls and several bins, granaries and a small oven (Fig. 10). It is not yet completely excavated, and it was significantly damaged by the Roman and Medieval pits, so it therefore

33 Mitkoski 2005. cannot be thoroughly described at this stage. Nevertheless, it has similar features to that of Buildings 1 and 2 despite other buildings which do not have burned daub walls or interior clay structures discovered so far. In terms of the other buildings, it should be asserted that only small parts of them were excavated or they were only recorded in the stratigraphic sections. Building 5 is on the same level and to the south of Building 2, but apart from posts, it does not have the remains of daub or other structures. Therefore, it 


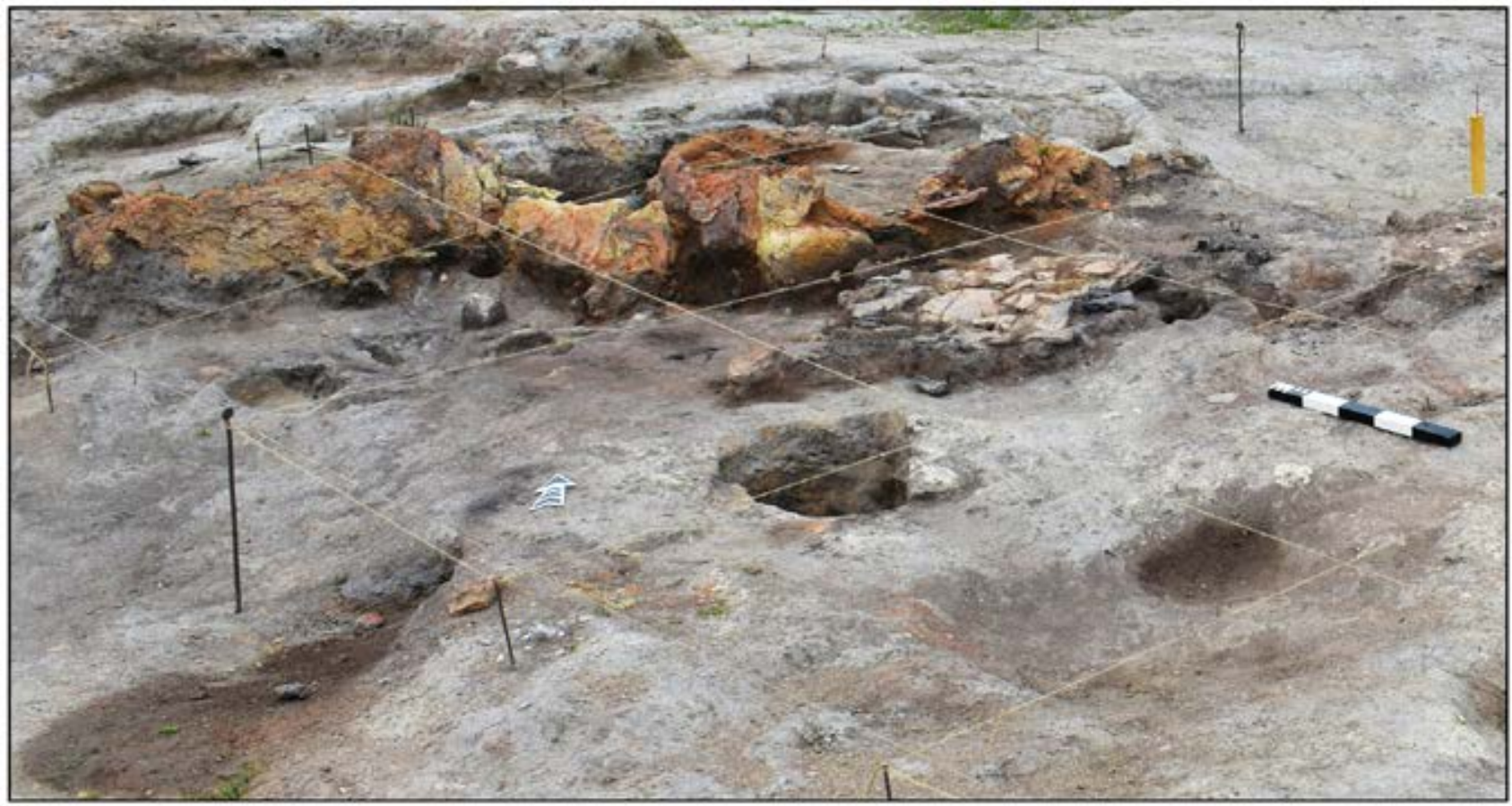

a

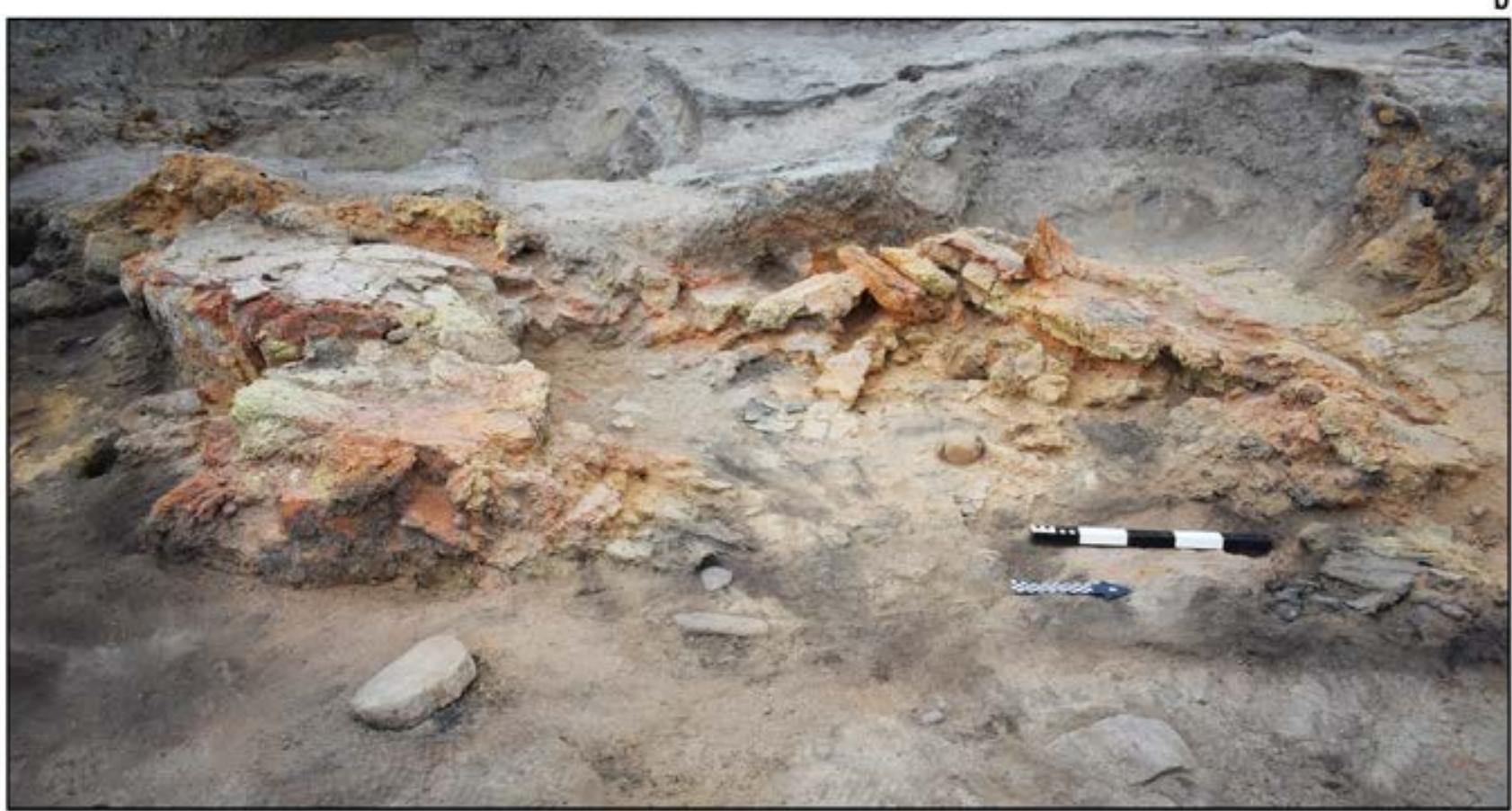

Fig. 11: Daub structures for processing of cereals and preparation of food in Building 2: a) Oven 47 with small bin and oval grinding area; b) Oven 322 with a processing platform, small bin and remains of upper floor with double bin fallen on the oven, as well as the foundation of a channel from the Building 14 that cut and damaged the oven (Photo: Goce Naumov). 
is not evident whether it is a lateral compartment to Building 2 or whether it functioned as an individual structure made only of dry daub which was found within its area. The same character can be attributed to Building 11, which is on the same level as Building 2 and 5, but was built from dry daub with thick layer of plaster as a floor or fundament above the natural deposit of sand.

Right above Building 11, the Buildings 7 and 10 were established and they presented similar architectural features. Buildings 7 and 10 were damaged by later pits, but also by the posts in the burned massive daub walls of Building 4 that was established on top of them. The buildings right above Building 4 also consist of burned daub walls and plastered floor, such as Buildings 6, 9 and 12 . Building 14 belongs to Horizon II and it is built above the aforementioned Building 4, but it is also different from all buildings below due to employment of channeled quadrangular foundations where the posts were dug (Fig. 10). The thin layers above it belong to Buildings 8 and 16, which reverted to earlier practices of walls made of dry daub and plastered floor. Building 15 is still dubious as it is not clear whether it belonged to a pit dwelling contemporary to Building 4 or it was a different structure significantly damaged by a large Medieval pit.

In sum, there were approximately 17 buildings recorded at Vrbjanska Čuka, of which few could be part of one unit. Although all of them were made of posts covered with clay, they differ in terms of later treatment of their walls. Namely, the majority have dry daub walls, but several (such as Building 2 and 4) consisted of heavily burnt daub walls. For some time, such walls were considered as a result of unintentional fire, but more recently a number of studies proposed deliberate burning of Neolithic houses ${ }^{34}$. The same could be suggested in the case of Vrbjanska Čuka, as there are several arguments in favor of this interpretation. The color of the daub indicates that the walls were exposed to long and intense burning which would not have happened in the case of unintentional fire due to the halt of its spreading. Also, the contemporary buildings next to Building 2 did not have any traces of burning which means that its firing was controlled and solely restricted to this structure. If the cleaning of this building and the placing the grinding stones upside down are also considered a practice of symbolic finalization of the house life, this could be proposed as for other Neolithic buildings in Macedonia and in the Balkans in general ${ }^{35}$.

34 Stefanović 1997; Chapman 2000; Tringham 2005; Gheorghiu 2007; Naumov 2013.

35 Fidanoski 2015.
As evidenced in the archaeological records from the Vrbjanska Čuka excavation, the firing of buildings was an isolated practice in different stages of the settlement. Referring to the stratigraphy of the site, it should be asserted that there is establishment of at least six buildings one on top of another. Consequently, due to this type of disposition of buildings and their distinct construction, a division of layers in three horizons is proposed solely based on architectural features and not on the material culture. In the first level of Horizon I, there were four buildings recorded right above the natural sand deposit, such as Buildings 1, 2, 5 and 11, whereas on the next level of the same horizon Building 7 and 10 were recorded. The next Horizon II is represented by Buildings 4 and 15 (Building 15 could be the remains of a pit dwelling) in the first level and Buildings 6, 9 and 12 constructed above, representing the next level. Horizon III represents the last stage of the Neolithic settlement, when Building 14 with channeled foundations was erected and with Buildings 8 and 16 from the level above as the final architectural activity in the Neolithic settlement.

It should be asserted as well that there are no sediments of natural deposit between any of the buildings mentioned above. This means that the buildings were constructed in a short temporal range without larger interruptions of household activities in this particular area of the excavation trench. After the abandonment of earlier buildings, new buildings were established on top with the only preparation consisting in the leveling of the remains and placing a plaster of whiteish clay above. For the moment, there are no dates for each of the recorded buildings which would enable the comprehension of the occupation period of each particular structure and the temporal dynamics of rebuilding new ones. Nevertheless, the dates from Building 2 as well as the dating of selected samples from the remaining ones will provide information on a time when these structures were established, used and abandoned.

\section{Architectural materials}

During the 2018 season at Vrbjanska Čuka, a program of studying the burnt daub found on site was initiated, the preliminary results of which are presented here. A total of 728 pieces of daub were recorded so far, most of them from the collapse of Building 2. The study is focused on daub shapes and impressions of vegetal materials and aims to reconstruct details of the construction of walls, roofs and installations that are not otherwise preserved in the archaeological record. The recording methodology used here was created using previous shape-focused daub 
studies as a basis ${ }^{36}$. Most of the collected pieces probably belonged to walls since they feature flat surfaces with impressions of parallel rounded pieces of wood on the back. On a majority of daub pieces, presumably belonging to the outer walls of buildings, the thickness of the daub layer that was applied onto the wooden framework ranged between $5-8 \mathrm{~cm}$. Assuming that a daub layer of equal thickness was applied on the other side of the wooden framework, and observing that the wood impressions on the back of the daub pieces in question seem to indicate wooden stakes with 7-9 $\mathrm{cm}$ diameter, the typical thickness of building walls can preliminarily be described as ranging from $17-25 \mathrm{~cm}$. Some recorded pieces show much thinner daub layers on wood $(<2 \mathrm{~cm})$; these thin walls might belong to internal walls or installations rather than outer walls. Some wall fragments carried plaster.

Other daub pieces featured wood impressions that attested to complex arrangements of wooden components and might belong to building corners, installations or the roof. The impressions in the Vrbjanska Čuka daub attest to the use of wooden components of very different sizes in building construction. Where impressions are preserved well enough to have preserved the complete diameter of wooden pieces, these diameters range from $0.5 \mathrm{~cm}$ to $8.8 \mathrm{~cm}$. However, much larger pieces were probably used without their impressions being completely preserved in daub. Most wood impressions were round, but a few were angled and attest to the splitting of wood pieces prior to their use in construction. Daub pieces that represent corners or edges display a wide variety of shapes from rounded to sharp corners which attests to the careful preparation of architectural components with different visual qualities at Vrbjanska Čuka.

Most pieces of daub show very similar inorganic inclusions: frequent inclusions of very small, glittering particles that probably represent mica; moderate amounts of very small $(>3 \mathrm{~mm})$ stones, most of them white, but some gray or black; and in few cases larger stones. The homogeneity of the inorganic inclusions shows that probably all studied daub pieces were made from the same clay source and/or had the same inorganic temper added. Botanical inclusions in daub represent a very interesting field of study. The Vrbjanska Čuka daub preserves traces of botanical inclusions mostly in form of voids, but in some cases the actual inclusions themselves were still preserved. The impressions are mostly of the stems of cereals or similar plants, although occasional grain impressions were also observed including a few entire wheat ears (e.g. Fig. 12). This shows that it likely was the leftovers of grain process-

36 especially Jongsma 1997; also see Chetwin 2007; Sherard 2009.

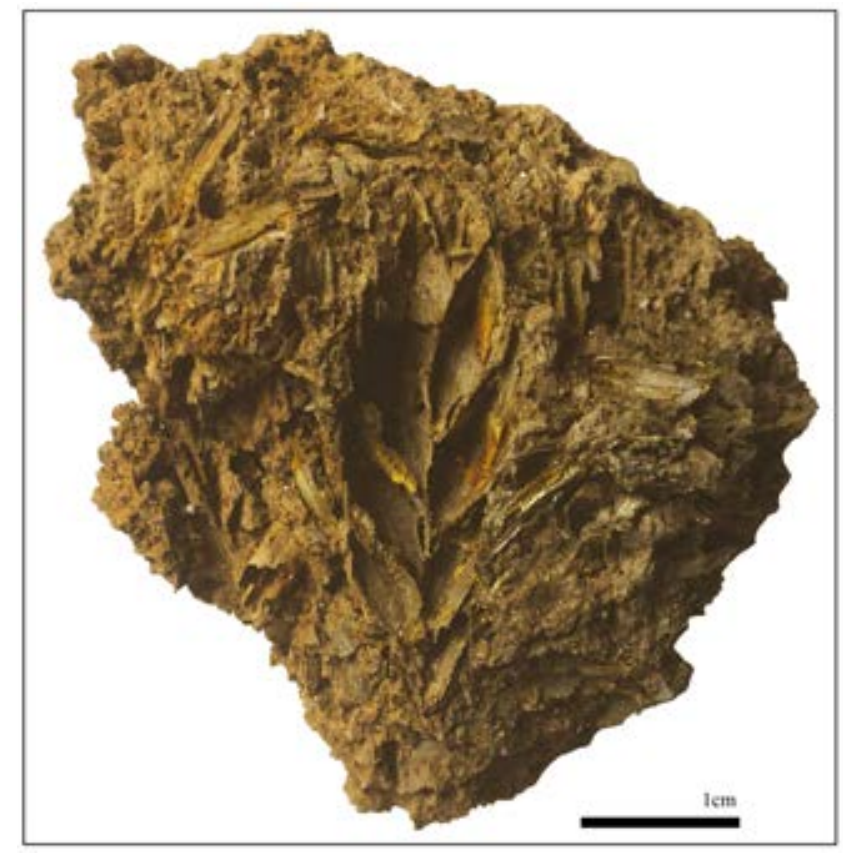

Fig. 12: Impression of a wheat ear and botanic macro-remains preserved in a piece of daub (Photo: Jana Anvari).

ing (chaff) that were added to the daub as temper. A future and more detailed study of the impressions and macro-remains using microscopes might, however, be able to establish in greater detail what plants and what sections of plants were used - including also the wood impressions.

\section{Material culture}

Neolithic sites in Pelagonia are commonly rich in finds made of clay, stone, flint and bone. The same could be confirmed for Vrbjanska Čuka as well, particularly after the detailed documentation of all finds and the analysis performed on some of them. The study of finds provides an insight into the economy and everyday life of the farming community inhabiting this tell, but also sheds more light on some of the social and symbolic components of vessels, figurines, models, altars, weights, sling shots, blades/ sickles, axes and needles produced and employed by the residents of the daub buildings. Considering the diversity of forms and types in each category of finds, it is clear that the community that inhabited Vrbjanska Čuka invested significant amounts of time and skill into the production of refined and representative objects beyond the requirements of their function.

Unlike ceramic finds, the number of artefacts made from stone and bone is far smaller. They belong to a category of tools used for cutting, slicing and drilling. Most 
common in this group are the stone axes of different dimensions and with well preserved edges, whereas only a few have bore-drilled openings for the insertion of a handle. The number of animal bones is surprisingly small (Tab. 3), which is also reflected in the quantity of tools made of this material, such as the spikes, needles and chisels found in the initial horizon. The flint tools are also present and were part of a closer analysis, discussed in detail below.

\section{Finds made of clay}

As on many archaeological sites the potshards are the most frequent ceramic finds, produced with high quality for Neolithic standards, so consequently a large number of them featured fine fabric. Such a concentration of vessels made from fine clay with a polished surface is not common for many other sites out of Pelagonia. However, despite the frequency of these vessels, their typology does not vary to a significant degree. Three basic types of vessels with fine fabric can be differentiated, such as dishes, pots and jars with high neck (Fig. 13). They were found in all horizons and in many contexts. Therefore, they are not to be distinguished as a reference for a stratigraphic definition of the settlement yet. A much more detailed study of vessels and the entire ceramic assemblage is necessary in order to define the social changes within the settlement, although an initial analysis of their typology and contents in their interior was already done ${ }^{37}$.

Pots and dishes dominate among the vessels with fine fabric. Pots are mostly of medium and smaller dimensions and are found in many colors: dark red, ocher, beige, brown, gray and black. Almost all colors were found in the three horizons, although the variations of red color are most frequent in all horizons. Red and black pottery is equally found even in Horizon I, i.e. the Early Neolithic, which contradicts the common consideration of black polished pottery as a feature of the Late Neolithic ${ }^{38}$. They were made of fine clay without any silicate or organic additives, color-coated and fired at a high temperature and polished afterwards so that high gloss could be achieved. Black pots have no decoration, but nipple-like applications on the slightly carinated parts. A significant quantity of carinated vessels were detected in Horizon III, so it could be considered as a later appearance, which is yet to be confirmed with a more thorough study.

37 Mitkoski 2005; Temelkoski/Mitksoski 2005; Naumov et al. 2018a; Naumov et al. 2018b; Stojanovski et al. 2020a.

38 Simoska/Sanev 1976; Garašanin 1979; Sanev 1994.
Red-colored pots were more decorated, so in addition to the nipple-like application on the most prominent part of the vessel, they also have white and black painted patterns. White painted patterns are rare but were found in the earliest layers of Horizon I and in the Horizon III as well. Such painting was evidently present throughout the entire period of the settlement's existence and was synchronously applied along black painted pattern on other vessels. Often, thin, white stripes and triangles were present, most probably part of the usual elongated patterns typical of Velušina-Porodin Culture in Pelagonia ${ }^{39}$. Black-painted patterns occurred in most of the pots entirely covered with a red color, but its composition cannot be determined due to the fragmentation of vessels. Usually, they were massive or consisted of thin vertical, horizontal and diagonal stripes, as well as zigzag lines which were not firmly fixed on the pottery during the painting and therefore remained pale, sometimes even hardly noticeable. They were also found in all three horizons, and consequently cannot be considered as a diagnostic feature of a specific phase of the settlement. Unlike the Amzabegovo-Vršnik group, where black painting was mainly employed during the Middle Neolithic, in Pelagonia this color was used even in the Early Neolithic ${ }^{40}$.

Apart from pots, jars with elongated necks were also found among those with a fine fabric. They were made of fine clay in brown, beige and gray colors and are mainly found in Horizon I and Horizon III. Furthermore, several legs were found from three- or four-legged vessels of fine fabric, otherwise rarely present in Pelagonia. It should be emphasized that they were not rhyta, but representative vessels used for food or liquids. Only spare legs of such vessels were recorded in multiple contexts (mainly in Horizon III), so their full appearance cannot be reconstructed.

Vessels with coarse fabric were presumably used for storage, while those with extra-large dimensions are rarely found. More frequent were the medium sized vessels, which could have been used for the transport of liquids and crops. They were made of relatively fine clay, but occasionally organic inclusions are found, such as straw. Their surface is not polished like on the vessels with fine fabric and most often their color is beige and reddish. Especially frequent are the amphora-like vessels, but there are also askoi, though in highly fragmented condition. They were found in Horizon II, but certain fragments suggest to their presence in Horizon I as well. Apart from these vessels,

39 Simoska/Sanev 1975; Simoska/Sanev 1976.

40 Grbić et al. 1960; Gimbutas 1974; Sanev 1995; Naumov 2015. 


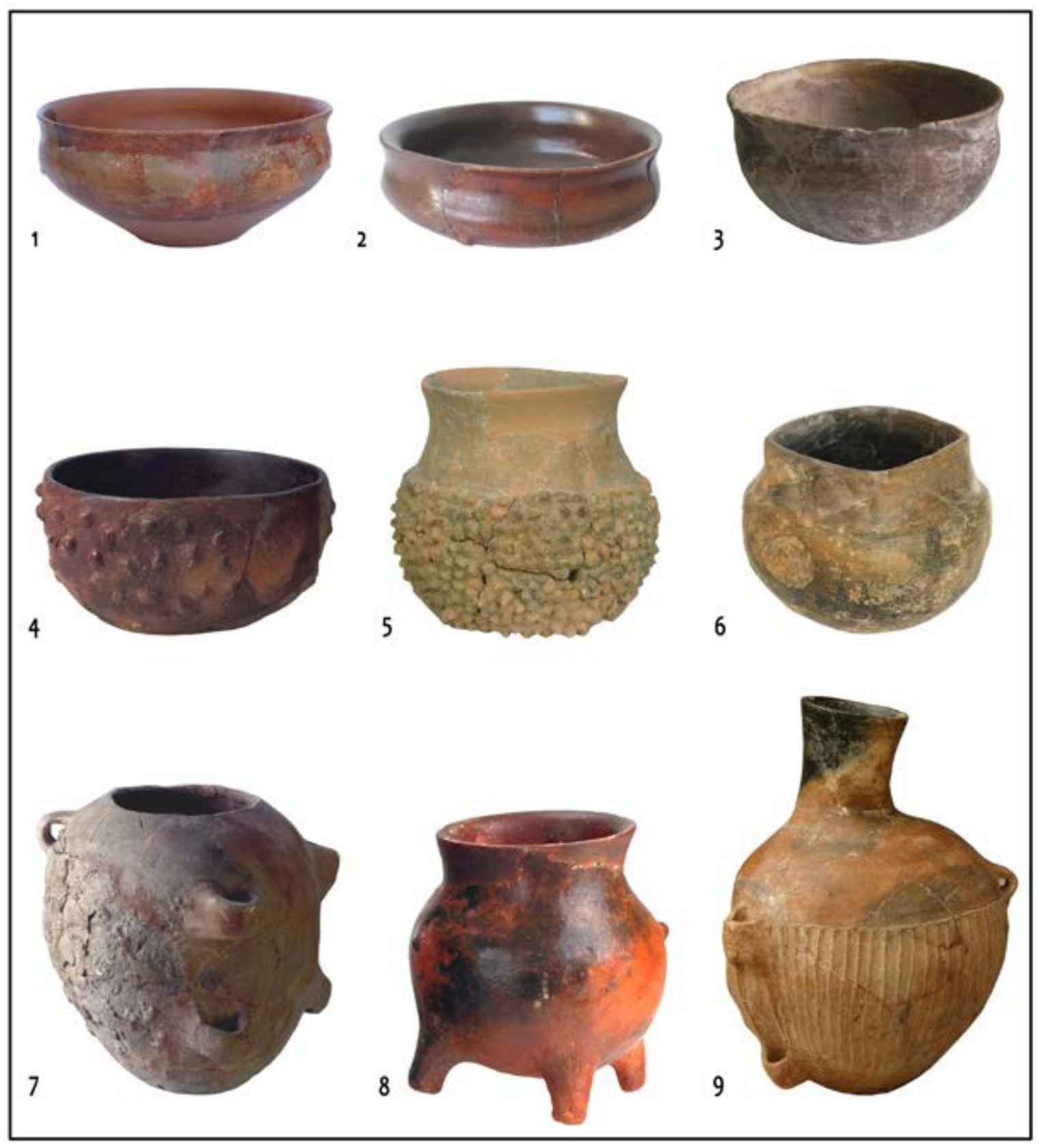

Fig. 13: Several types of Neolithic pottery common for Vrbjanska Čuka (Photo: Aleksandar Mitkoski).

there are entirely preserved vessels of smaller size whose function is hardly determinable at this stage of research.

As for the vessels with a coarser fabric, their decoration was often made by pinching and barbotine, present from Horizon I onwards, but is not as frequent as in Neolithic sites elsewhere in Macedonia. Pinching was sometimes used for producing triangular shapes, while nail embossing, although seldom, was present on the applied bands. Other types of applied bands often have impressions typical for the Neolithic vessels in the Balkans and they were rarely modeled in a zigzag line. Moreover, there are also bands, i.e. more massive clay ribs inside the vessels which served for holding strainers. Button-like applications were also present, which is a common feature in the broader region. The incision is one of the more frequent decorative techniques in vessels with a coarse fabric. This technique was used for diagonal, vertical or horizontal lines, but also for concentric circles and rhombuses. Some vessels even have bottoms with impressions which were not a part of the decoration, but a negative of the straw mat on which they were laid prior to firing or while drying. 
So far in Vrbjanska Čuka, 24 base fragments from ceramic vessels with preserved negative imprints of a textile were documented although similar marks were recorded on the anthropomorphic house models, altars and daub as well. One technique of weaving is identified, a double weft twining with two variants, such as the tight simple S-twist twining where the rows of the wefts are tightly packed (recorded on 20 bottoms). Also, the closed simple S-twist twining is documented where the rows are slightly separated (evidenced on four bottoms), as well as a simple S-twist twining where the warps are slightly separated (evidenced on one bottom). The imprints are always on the outside of the vessel base, which indicate that the textile most likely originated from a ragged cloth or blanket used either to protect the pottery from contamination by dirt while drying, or as a support while raising the vessel ${ }^{41}$. These textile imprints on pottery from Vrbjanska Čuka demonstrate that a developed phase of the textile industry had been present in this settlement since the Early Neolithic. There is still no information for the material used in producing the textile, since flax has not yet been found at the site, but nettle (Urtica dioica) has been identified in the archaeobotanical record.

Among ceramic objects, those of symbolic character stand out, such as figurines, anthropomorphic house models and tablet-altars. Most often, figurines depict people or cattle and are more frequent in Horizon III compared to the first two horizons, where they have rarely been found so far. Anthropomorphic figurines are usually columnar, with emphasized stylization, i. e. the absence of limbs and a face (Fig. 14). In some cases, the arms are only indicated and body-tight, whereas the face sometimes consist solely of applied eyes. Some figurines of such typology have pronounced thighs and plate-like applications over the genitalia or the waist which is common for such objects in Pelagonia ${ }^{42}$. Animal figurines are rare, and the cattle representations are the only ones that could be determined so far. Two examples stand out among animal figurines: one with a recipient on its back and the other with applied zigzag leg patterns. Both contain elements typical of altars, so visually and functionally they belong to both categories of objects.

Altars (also known as tablets) are frequently present from the initial horizon onwards and bear the usual characteristics for such objects, like legs with zigzag application and a recipients braided with an applied ribbon, sometimes consisting of carved lines (Fig. 14). Their size

41 Mazăre 2012: 39; Özdemir 2007: 74.

42 Simoska/Sanev 1976; Naumov 2016a; Naumov 2020. is smaller, while their color is usually creamy and rarely reddish-brown. The fragments of anthropomorphic house models should be considered in the same manner. These models were found in all Neolithic horizons and bear the typical features, even though they are fragments only from the cube and rarely the cylinder. Most of them were rectangular cubes with big openings, typical for the northern parts of Pelagonia, but there were also some bearing the same zigzag applications at the lateral apertures as the altars ${ }^{43}$. In addition to the cubes, several cylinders with central openings on the top and traces from burning, i.e. from smoke that exited from the opening, were also recorded. The dimensions of these finds are relatively large, their color is usually creamy and brown, the fabric is intermediate, without additives of organic and mineral temper. None of the cylinders found so far have distinct face representation, although their fragmentation should be considered, as well as the rare presence of these elements in the northern parts of Pelagonia.

Among the small clay objects particularly interesting are the so-called labrets and the small conical objects made of clay resembling stamps, but without carved or applied patterns that should be impressed on a soft surface. They are assumed to have been tokens or calculi, i. e. objects used in games, economy, rites etc. ${ }^{44}$. Similar to these are the flat tokens which could have had the same purpose. In this regard, also worth noting are the smaller or bigger discs made of vessel fragments and perforated in the center. They were most probably used for spinning, as loom weights or for fishing nets. Clay was also used in the production of bracelets and for modeling of the so-called bread models. The clay sling shots are also common in Vrbjanska Čuka and they have smaller dimensions, an ellipsoidal shape, as well as a red or brownish color due to firing. Their presence is quite frequent compared to the other regions in Macedonia where they are completely absent or extremely rare ${ }^{45}$. The last among ceramic objects are the massive finds of conical and rectangular shape and their function is unclear. They are thought to be vessel plugs, bases or objects that have symbolic features.

\section{Use-wear analysis of lithic tools}

The use-wear analysis was mainly focused on the study of the so-called glossy blades, their morphological, techno-

43 Temelkoski/Mitkoski 2005; Naumov 2016a. 44 Nilhamn 2002; Bennison-Chapman 2019.

45 Simoska/Sanev 1976; Kitanoski 1977; Simoska et al. 1979; Naumov/Tomaž 2015. 


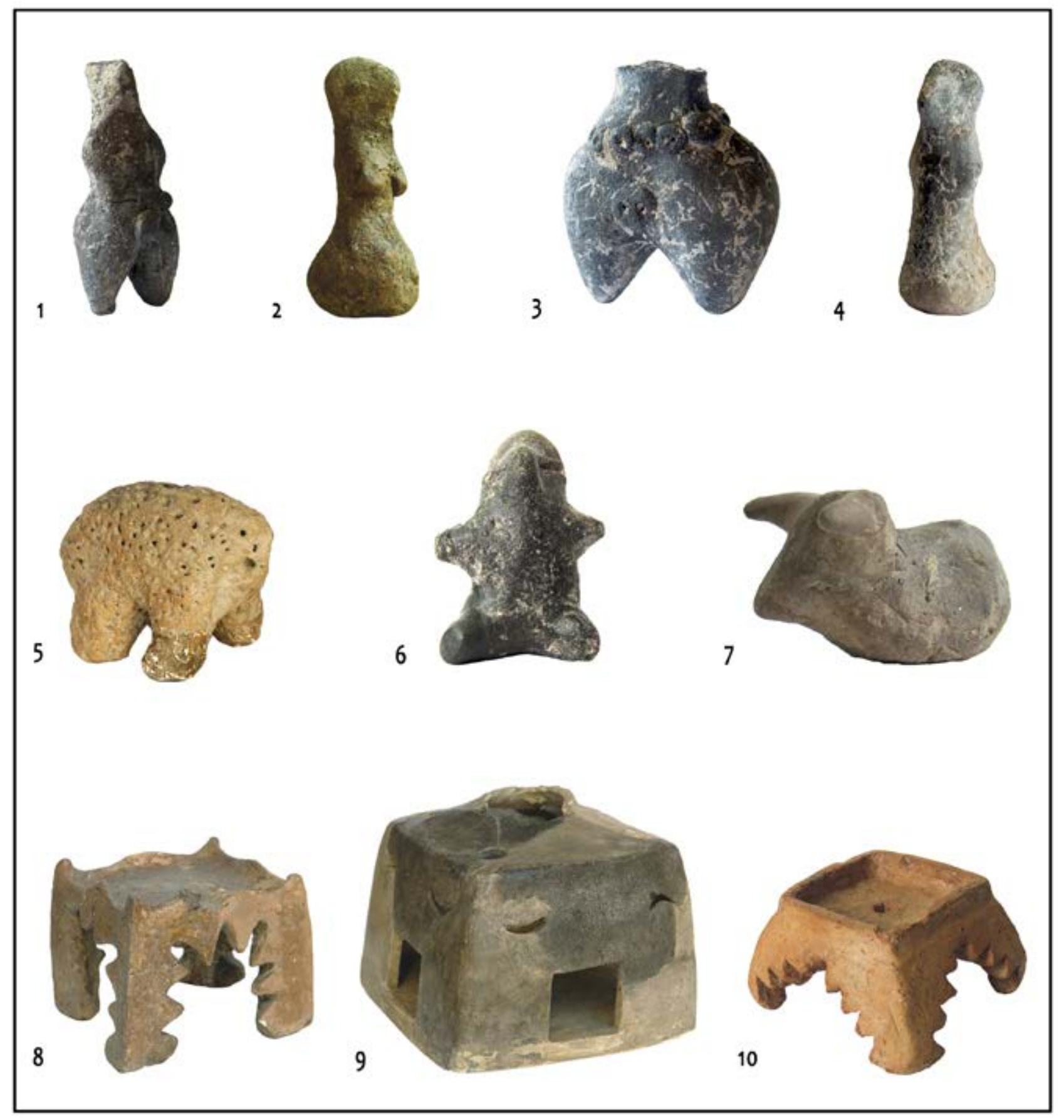

Fig. 14: Figurines, anthropomorphic house model and altar-tablets typical for Vrbjanska Čuka (Photo: Aleksandar Mitkoski).

logical, and functional variability ${ }^{46}$. The sample of materials analyzed in this study amounts to 47 items. All of them were subjected to macro- and microscopic observation in order to highlight the potentially used edges. A more detailed analysis of the use-wear traces has been carried out only for tools used in cereal harvesting (Fig. 15). The

46 Gibaja et al. 2017; Mazzucco et al. 2017. standard use-wear methodology has been used for their analysis, integrating both a macro- (magnifications between $5 x-40 x$ ) and a microscopic scale of analysis (magnifications between 50x-400x). As result of the analysis, 18 glossy blades have been detected. Of them, three tools show two active edges, while one tool shows up to three used edges; therefore, a total of 23 edges used have been recognized. 


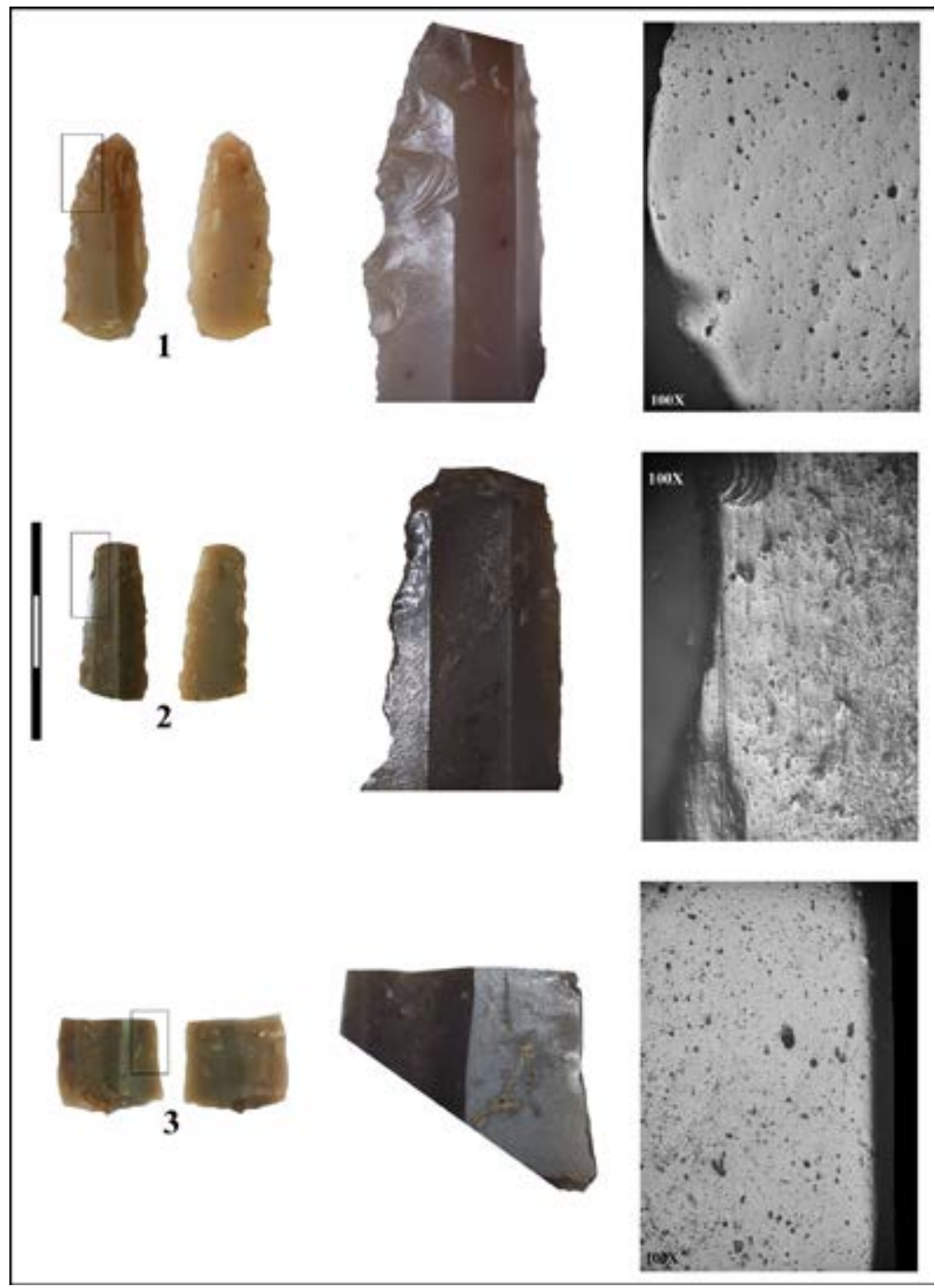

Fig. 15: Flint tools and microscopic images with trace of use-wear (Photo: Niccolo Mazzucco and Juan F. Gibaja).
Blade blanks prevail ( $n=15)$, while only three flakes were used to produce harvesting inserts. Tools were made of at least four different varieties of chert: 1) a honey colored, massive, fine-grained chert; 2) a gray-colored, massive, fine-grained chert; 3) a dark, black- to graycolored chert, occasionally with reddish tonalities, characterized by a coarser texture than the previously mentioned chert-types; 4) a gray-colored, medium-grained chert, characterized by abundant calcareous inclusions. This classification has been made on the basis of the first macroscopic observation of the material and should be taken as preliminary. Still, for being such a small sample, the diversity of raw-materials exploited is quite high, suggesting that different strategies of lithic raw-material acquisition and reduction were undertaken by Vrbjanska Čuka groups.

The average dimensions of the inserts are between $40-30 \mathrm{~mm}$ in length, $15-20 \mathrm{~mm}$ in width and $4-5 \mathrm{~mm}$ thickness. All of them have been made on blade or flake fragments, voluntarily broken before the use. Inserts were likely produced through different methods. Blades on fine-grained cherts were flaked by pressure, given their extreme regularity, while inserts on less homogeneous raw materials were probably flaked through other techniques. However, a larger sample of artefacts it is necessary to explore more in detail for techno-economic issues.

All analyzed inserts highlighted the presence of diagonally distributed glossy surfaces. This type of use-wear is produced when the inserts are hafted into curved sickles to form serrated cutting-edges. From a microscopic view, traces show the typical pitted and striated polish produced by cereal harvesting. Despite that, variations in the quantity of striations and abrasions on the lithic surfaces can be highlighted from one insert to another, suggesting variations in the harvesting motion and gesture. Cereal glossis are generally well-developed, indicating a very prolonged utilization of the inserts, for dozens of hours of harvesting. In addition, of the 23 used edges, 14 edges have been 
Tab. 2: List of samples taken in 2019 and included in this paper.

\begin{tabular}{|c|c|c|c|c|c|}
\hline Sample code & Quadrant & $\begin{array}{l}\text { Stratigraphic } \\
\text { Unit }\end{array}$ & Volume (L.) & Unit description & Horizon \\
\hline VC19_S_05 & 25 & 461 & 6 & latest Neolithic layer in q. 25 & III \\
\hline VC19_S_06 & 24 & 463 & 9 & latest Neolithic layer in q. 24 & III \\
\hline VC19_S_10 & 25 & 486 & 12 & burnt area bellow dry daub from building above Building 2 & II \\
\hline VC19_S_11 & 32 & 490 & 2.5 & $\begin{array}{l}\text { pit in the burnt area } 486 \text { bellow the dry daub above } \\
\text { Building } 2\end{array}$ & II \\
\hline VC19_S_12 & 25 & 479 & 4 & $\begin{array}{l}\text { plaster from building right bellow the latest Neolithic layer } \\
(463)\end{array}$ & III \\
\hline VC19_S_13 & 16 & 488 & 12 & $\begin{array}{l}\text { level below plaster } 479 \text {, bellow the upper most Neolithic } \\
\text { layer (463) }\end{array}$ & III \\
\hline VC19_S_15 & 25 & 521 & 0.6 & $\begin{array}{l}\text { in situ burnt post in-between north wall of Building } 2 \text { and } \\
\text { Bin } 501\end{array}$ & I \\
\hline VC19_S_17 & 24 & 519 & 1 & Post hole south from a group of posts from Bulding 16 & III \\
\hline VC19_S_18 & 26 & 325 & 1.1 & $\begin{array}{l}\text { easternmost post hole from a cluster of post holes in } \\
\text { north wall of Building } 2 \text {, there is also a burnt area next to } \\
\text { it and two oval bins for processing cereals ( } 270 \text { and } 271)\end{array}$ & I \\
\hline VC19_S_21 & 16 & 520 & 2 & post hole in Building 10 , the third earliest building & I \\
\hline VC19_S_27 & 26 & 525 & 0.7 & Burnt area around oven 322 & I \\
\hline VC19_S_40 & 16 & 508 & 1.8 & $\begin{array}{l}\text { test pit/section in quadrant 16; burnt thin sediment on } \\
\text { the floor of Building } 4\end{array}$ & II \\
\hline VC19_S_41 & 25 & 503 & 0.08 & plaster from one of the uppermost buildings $=9$ & III \\
\hline
\end{tabular}

retouched in order to prolong their cutting effectiveness. This data points out toward a strong exploitation of the available edges.

In conclusion, Neolithic groups at Vrbjanska Čuka were using sickles with serrated cutting-edge to harvest cereals. This type of harvesting tool is quite common in the Central and Eastern Mediterranean, even if regional differences in the size and the type of used inserts can be highlighted. Future analysis will provide more detailed insight into the Vrbjanska Čuka lithic assemblage, integrating these results into a broader perspective.

\section{Archaeobotanical analysis}

Archaeobotanical research at Vrbjanska Čuka started in 2016, but the data generated until 2018 (including botanical macro- and microremains) is still under analysis ${ }^{47}$, and we will focus on the results obtained in the last field campaign ${ }^{48}$. During the 2019 campaign at Vrbjanska Čuka, a total number of 43 samples were retrieved from different deposits and buildings. Twenty samples were sieved, with a total amount of almost 95 liters of sediment, but the focus will be on the 13 samples that have been completely analysed so far, which adds up to the amount of 52.2 liters of sediment (Tab. 2). The wash-over technique was used in order to recover the maximum number of plantmacroremains possible ${ }^{49}$. No pre-treatment was necessary to apply other than soaking the sediment before sieving. One of the field stations of the IPAS (Institute for Prehistory and Archaeological Science) was used.

A considerable number of plant remains (almost 2500 remains) was recovered in the analysed samples. The large majority belongs to crop remains (cereal chaff, in particular), but also considerable amounts of herbaceous and other wild plants were encountered. Up to 35 taxa have been identified in the preliminary work done during the 2019 fieldwork campaign. The majority of remains are found in a charred state, but some mineralised remains were also recovered. At this moment it is unclear if these mineralised remains are Neolithic, since they were predominantly found in the uppermost layers and they may be contaminations from later Roman or Medieval deposits, as was suggested in the previous studies which regarded charred remains recovered from contexts excavated in $2016^{50}$.

The samples presented varied densities of remains per litre (r/L) of sediment, from below $2 \mathrm{r} / \mathrm{L}$ to almost 1000

49 Kenward et al. 1980; Steiner et al. 2015 50 Beneš et al. 2018.
47 Beneš et al. 2018. 48 Antolin et al.2020.

50 Beneš et al. 2018. 
r/L (Fig. 16). No mass finds were identified. Among the samples with densities above $100 \mathrm{r} / \mathrm{L}$, we could observe two different groups: one quantitatively dominated by chaff remains and the other one dominated by weeds (and chaff). One sample shows values of medium densities (ca. $80 \mathrm{r} / \mathrm{L}$ ), with a mixture of grain and chaff remains. The samples with lower density values (below $20 \mathrm{r} / \mathrm{L}$ ) were of mixed composition, some with more grain and chaff or chaff and weeds. There is no spatial patterning visible at the moment, each sample showing a different composition, which suggests a reasonably low post-depositional affectation of the samples.

Among the cultivated plants, several cereal and legume species have been identified. Among the cereals, einkorn (Triticum monococcum) is the best-represented taxon, with some finds of the 2-grained type. There are also grains and chaff remains of emmer (Triticum dicoccon) and a few of barley (Hordeum vulgare), including naked and hulled forms. Among the pulses, pea (Pisum sativum) is the best represented crop, but additional single finds of lentil (Lens culinaris) and possibly bitter vetch (cf. Vicia ervilia) have occurred. Potential cereal-based food remains were recovered, particularly in the area around the oven SU 322, which will require further investigation. Additionally, wild edible plants were also recovered, such as sloe (Prunus spinosa), bramble (Rubus fruticosus) or elderberry (Sambucus nigra), as well as fat-hen (Chenopodium album). Some interesting wild plants, indicative of wetlands nearby the site have also been identified at a preliminary level, such as Scirpus lacustris, cf. Eleocharis sp., or Lycopus europaeus. Among the potential weeds, ruderals and grassland plants we can highlight the presence of Bromus sp., Chenopodium album, Verbena officinalis, Polygonum aviculare, Urtica dioica, Melilotus sp., Rumex acetosa, Plantago lanceolata and Galium sp.

The cereals were mostly represented as chaff remains (Fig. 16). Einkorn dominated in most samples, where emmer was also well-represented. Barley was present in several samples, but always in small amounts. Grains also show a similar trend, with more remains of einkorn, followed by equal number of finds of barley and emmer. All of the mentioned cereal species were found in most of the samples and phases. This suggests a considerably diverse crop spectrum that is in accordance with the available data from nearby regions ${ }^{51}$, but there seems to be a clear focus on einkorn at Vrbjanska Čuka.

Gathered plants were also found, particularly in burnt layers associated with other food consumption residues,

51 Allen/Gjipali 2014; Marinova 2017; Marinova et al. 2016. but mostly in small numbers, which is common in dry sites where wild edible plant foods are normally underrepresented $^{52}$. Their presence, even when in small numbers, must be considered as an indicator of their importance as a food resource. The remarkable preservation conditions, together with a more thorough taphonomic analysis will allow us to further define activity areas, to understand refuse management and better characterize plant economy at this important site.

\section{Archaeozoological analysis}

The archaeozoological analysis provided insight into animal husbandry strategies on the basis of the taxonomic composition and reconstructed mortality profiles of domestic mammals, the use of additional dietary sources (freshwater mussels, wild game and fish), and patterns of food waste deposition within the Neolithic settlement. Moreover, the analysis of minute and porous remains of micromammals and non-mammal fauna, whose collection was enabled by flotation, enabled a better understanding of the past environment of the site. The total number of identified specimens (NISP) in the assemblage collected in 2016-2018 by hand and flotation is 1052 (Tab. 3). The vast majority (649, i.e. $61.7 \%$ ) originated from large mammals, and mollusc shells were also present in fairly large numbers (203, i.e. $19.3 \%$ ). The remains of other taxa - micromammals, birds, amphibians, reptiles and fish were fewer in number, given that only selected sediment samples were given to flotation.

Mammal remains are indicative of a predominantly stockbreeding economy, as bones of domestic animals (sheep Ovis aries, goat Capra hircus, cattle Bos taurus and pig Sus domesticus) dominate the sample. More precisely, they constitute $95.1 \%$ of all large mammal remains identified to the level of species or genus. The high percentage of cattle bones is a fairly uncommon feature compared to other Neolithic assemblages in Macedonia and in the Southern Balkans in general, where caprines are usually most frequent, or even represent an overwhelming majority $^{53}$. Nonetheless, the archaeozoological record from Vrbjanska Čuka might be best explained as an outcome of a mixed herding strategy, which included caprines, a high proportion of cattle (especially significant if the meat yield

52 Antolín and Jacomet 2015; Jacomet et al. 1989. 53 Bökönyi 1976; Schwartz 1976; Lasota Moskalewska 1985a; Lasota Moskalewska 1985b; Lasota Moskalewska/Sanev 1989; Ivkovska 2009; Manning et al. 2013. 


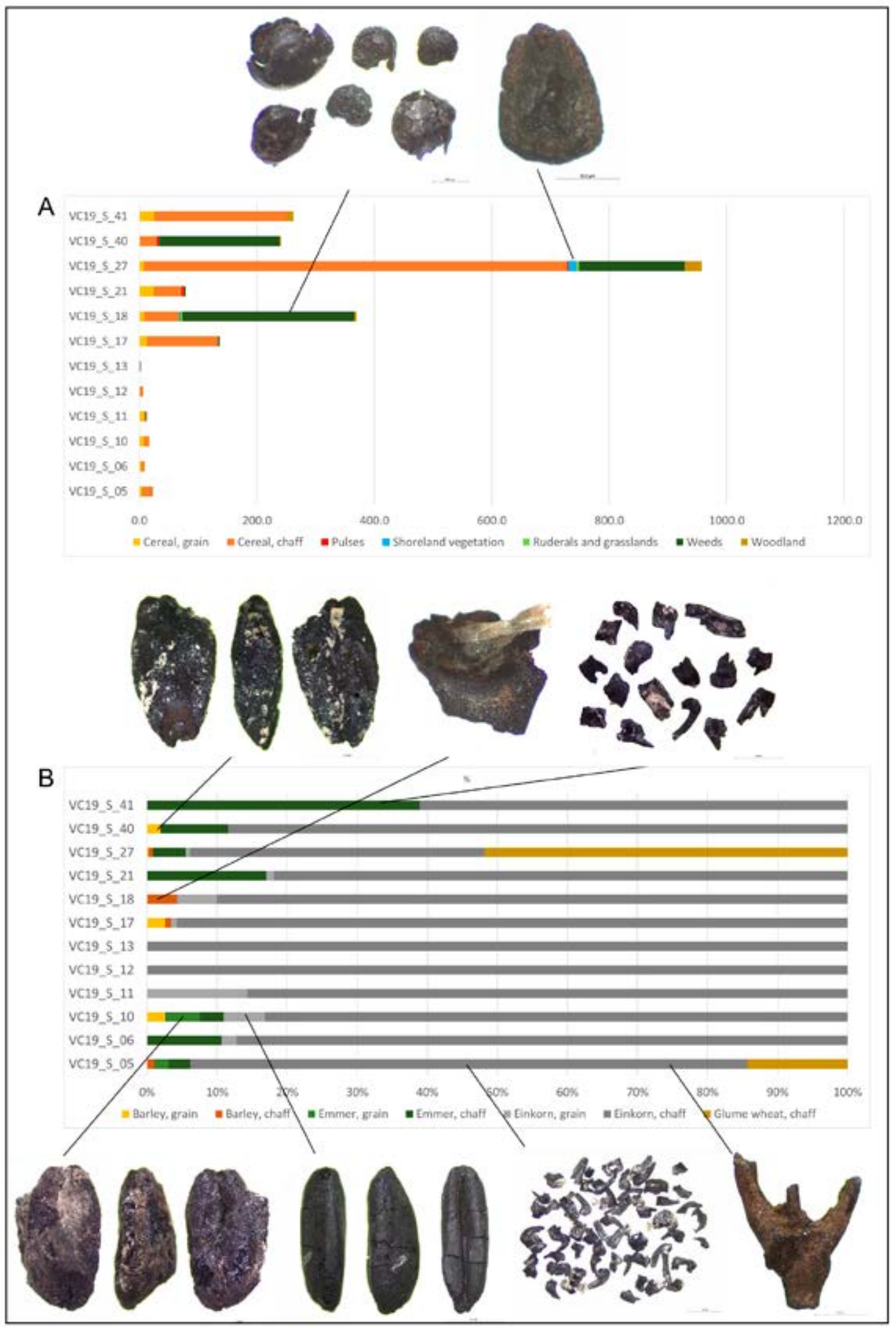

Fig. 16: Results of the archaeobotanical analysis. A: density of remains per litre, taxa presented according to ecological groups. B: proportions of the main cereal crops per sample. Pictures from top to bottom, left to right: Chenopodium album, Lycopuseuropaeus, Hordeum vulgare s. I. (grain), H. vulgares. I. (rachis segment), Triticum dicoccon (glume bases), T. dicoc. (grain), Triticum monococcum 2-grained type (grain), T. monoc. (glume bases), T. monoc. (spikelet fork). (Photo and graphs: Ferran Antolin and Raül Soteras). 
is taken into account), and, to a lesser extent, pig. The only other domestic animal present on site was the dog, and the negligible amount of their remains (NISP $=2$ ) is a common feature observed in other Neolithic assemblages in Macedonia and in the Balkans in general.

Tab. 3: The taxonomic composition of the faunal assemblage from Vrbjanska Čuka, collected by hand and flotation in 2016-2018.

\begin{tabular}{|c|c|c|}
\hline \multicolumn{2}{|l|}{ TAXON } & \multirow{2}{*}{ NISP } \\
\hline \multirow[t]{16}{*}{ Mammalia } & Canis familiaris dog & \\
\hline & Vulpes vulpes fox & 4 \\
\hline & Sus domesticus pig & 48 \\
\hline & Sus sp. & 3 \\
\hline & Cervus elaphus red deer & 4 \\
\hline & Capreolus capreolus roe deer & 1 \\
\hline & Bos taurus cattle & 88 \\
\hline & Bos sp. & 2 \\
\hline & Ovis aries sheep & 48 \\
\hline & Capra hircus goat & 9 \\
\hline & Ovis/Capra & 98 \\
\hline & Ovis/Capra/Capreolus & 1 \\
\hline & Bovidae indet. & 1 \\
\hline & Ruminantia indet. & 2 \\
\hline & Mammalia indet. & 338 \\
\hline & TOTAL & 649 \\
\hline \multirow[t]{8}{*}{ Micromammalia } & Talpa europaea European mole & 1 \\
\hline & Insectivora indet. & 4 \\
\hline & Spalax leucodon lesser mole-rat & 1 \\
\hline & Arvicola terrestris European water vole & 1 \\
\hline & Microtinae indet. & 12 \\
\hline & Mus musculus house mouse & 3 \\
\hline & Muridae indet. & 5 \\
\hline & Rodentia indet. & 3 \\
\hline Aves & Aves indet. & 20 \\
\hline \multirow[t]{3}{*}{ Herpetofauna } & Anura indet. & 15 \\
\hline & Lacerta viridis European green lizard & 3 \\
\hline & Herpetofauna indet. & 77 \\
\hline \multirow[t]{3}{*}{ Pisces } & Cyprinidae indet. & 34 \\
\hline & Salmonidae indet. & 9 \\
\hline & Pisces indet. & 12 \\
\hline \multirow[t]{3}{*}{ Mollusca } & Unio crassus thick shelled river mussel & 177 \\
\hline & Unio sp. & 23 \\
\hline & Anodonta sp. & 3 \\
\hline
\end{tabular}

It was possible to determine the individual age of economically important domestic animals only in a limited number of specimens, therefore detailed mortality profiles could not be constructed. Nevertheless, they provide at least the basic information on the age structure of slaughtered animals. The individual age was estimated on mandibles and lower teeth (Fig. 17), on the basis of criteria for dental development and wear stages proposed by several authors ${ }^{54}$. The age structure of domestic animals suggests that they were often slaughtered at a young age, which is probably related to meat exploitation and, in case of ruminants, at least to some extent to milk exploitation, as dairy fats were detected in one pottery vessel from Vrbjanska Čuka ${ }^{55}$. Young animals were particularly well-represented in the pig faunal sample, whereas in case of sheep and goat, some individuals were kept alive long after reaching sexual maturity. One sheep mandible and one goat mandible displayed irregular teeth wear, i.e. deformations as a result of illness, which is indicative of certain difficulties in stockbreeding and their consequences for animal health.

In terms of contextual provenance, the majority of remains of domestic animals originated from buildings and surrounding areas, and the body part distribution, fragmentation pattern and observed butchery marks suggest that they predominantly represent food waste. A particularly large amount of bones had been found in association with Building 2 (either within the building or in its immediate vicinity), as well as within and outside of Building 4. Few elements were articulated, apart from a radius and ulna of a pig from Building 2, a sheep calcaneus and astragalus found within the daub layer of this building, and a sheep metapodial bone and phalanx I found in a post-hole. Given that a significant amount of bones had been covered with a carbonate crust, butchery marks could have been observed only on a limited number of elements - a distal part of a cattle humerus with several cuts on the medial and lateral side, indicative of dismembering, found outside of Building $2^{56}$, and a cattle astragalus with butchery marks on the distal condylus, found in the topmost Neolithic layer. In addition, anthropogenic modifications other than butchery were observed on a sheep cranial fragment found next to the oven in Building 2 and a sheep scapula found in a Neolithic pit next to Building 2. The cranial fragment bore a $5 \mathrm{~mm}$ wide perforation on the temporal bone, whereas the scapula blade had also been perforated. It is also worth noting that caprovine tibiae were commonly used as raw material for making a specific kind of tool with a recipient, often interpreted as a "spatula-chisel" and two such artefacts (both carbonized) have been found at Vrbjanska Čuka ${ }^{57}$.

54 Matschke 1967; Silver 1969; Bull/Payne 1982; Grant 1982; Habermehl 1985; Hambleton 1999; Halstead et al. 2002; Payne 1985; Carter/ Magnell 2007; Vigne/Helmer 2007; Gillis 2012.

55 Stojanovski et al.2020a.

56 Naumov et al. 2018b, Fig. 14.1.

57 Ibid. Fig. 14.2b. 


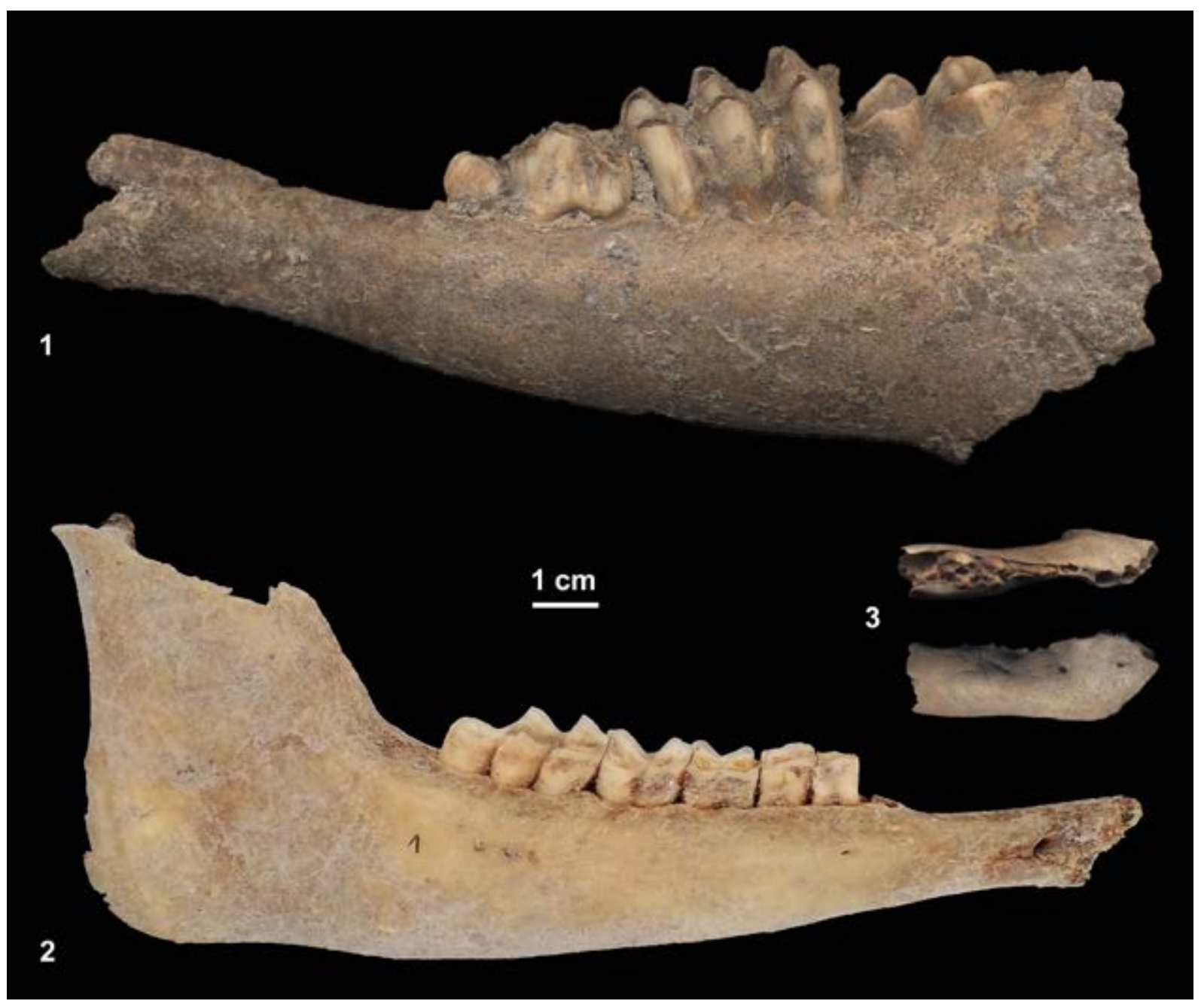

Fig. 17: Mandibles of domestic animals: 1) left mandible of a calf (Bos taurus) with milk molars and the first permanent molar in the process of eruption, aged 3-6 months (Sq. 18, Context 166, the compact sediment above Building 4); right mandible of a very old (8-10 years) sheep (Ovis aries), with significantly worn premolars and molars (p3-m3) (Sq. 17, Context 166, the compact sediment above Building 4); 3) right mandible of a newborn piglet (Sus domesticus) with milk molars in the process of eruption (Sq. 27, Building 2). (Photo: Ivana Živaljević).

Although fairly modest in comparison to the ratio of domestic animals, the presence of wild animal remains is indicative that hunting also took place (Tab. 3), most likely in the forests on the mountain slopes bordering Pelagonia. Sporadic finds of red deer (Cervus elaphus) and roe deer (Capreolus capreolus) bones show that these animals were occasionally hunted for food. In addition, one red deer tine fragment from the upper daub layer in Building 2 bore zig-zag cut traces (probably manufacture waste), which suggests that antler was also used as raw material. Apart from game animals, several fox (Vulpes vulpes) bones were also identified. These animals were possibly hunted for fur.

In addition to mammal remains, a significant part of the faunal assemblage consisted of freshwater shells.
Their presence is an indicator of the past wetland environment of Pelagonia given that, prior to the establishment of irrigation systems in the 1960s, there was a number of small rivers, marshes and small lakes in the area ${ }^{58}$. At Vrbjanska Čuka, the thick-shelled river mussels Unio crassus of various sizes were most commonly collected, and occasionally Anodonta sp (Tab. 3). Particularly significant amounts of Unio shells have been discovered in Building 2. They were probably used for food (and possibly as fishing bait), given that a number of them (mainly larger specimens) were broken on the anterior or the posterior part of the valve. It is of particular interest to note that traces of

58 Trifunovski 1998; Naumov 2016a; Naumov et al. 2018b; 2020. 
shell nacre (mother of pearl) were observed under a binocular microscope on the surface and especially the edge of an axe found in a large post-hole; such tools were most likely used for opening bivalve molluscs ${ }^{59}$. Similar shell breakage patterns have been observed on Unio specimens from several prehistoric sites in Serbia: at the Mesolithic site of Kula and the Early Neolithic site of Drenovac ${ }^{60}$. In Macedonia, Unio sp. shells have been found at the Early Neolithic site of Tumba Madžari, however in modest amounts ${ }^{61}$.

As previously noted, the flotation of selected sediment samples enabled the collection of taxa of small body size micromammals, birds, amphibians and reptiles, and fish; only the fish could be unequivocally associated with human consumption. As previously noted, the former, wetland landscape certainly provided ample opportunities for fishing. At present, the major rivers in Pelagonia and Mariovo are the Crna Reka (prior to regulation, abundant in fish fauna), Dragor, Bošava and Došnica. All of them are lowland rivers populated by cyprinid species (i.e. the family of carps and minnows), apart from the upper reaches of Dragor, which represent a salmonid zone ${ }^{62}$. The remains of representatives of these two families - i.e. small-bodied cyprinids and salmonids - have been identified in the faunal sample from Vrbjanska Čuka (Tab. 3). Nevertheless, fishing seems to have been of lesser importance in comparison to stockbreeding and shellfish collection, possibly a supplementary or opportunistic activity. In addition, the bird remains from Vrbjanska Čuka could have also been deposited as a result of human agency, i. e. they could be indicative of fowling.

The remains of other taxa collected by flotation were not deposited by humans, but represent species which inhabited the wider surroundings of Vrbjanska Čuka or the settlement itself. Concerning micromammals (Tab. 3), the remains of two burrowing species were identified - the European mole (Talpa europea) and the lesser mole-rat (Spalax leucodon), and one semi-aquatic species - the European water vole (Arvicola terrestris). Whereas the presence of these species provides important data on the past environment of the site, unrelated to human activity, the house mouse (Mus musculus), whose remains were also identified, was an "uninvited guest" in agricultural settlements. However, so far, there has been little evidence of this commensal species in Neolithic settlements in the Balkans. House mouse remains have been documented

59 Naumov et al. 2018b, 277.

60 Živaljević et al. 2017; Stojanović/Obradović 2016.

61 Lasota Moskalewska/Sanev 1989.

62 Ristić 1977, 25. so far at the Late Neolithic site of Vinča in Serbia and the Chalcolithic tell of Bucşani La Podin in Romania ${ }^{63}$. Consequently, to the best of our knowledge, the remains of house mouse from Vrbjanska Čuka represent the first evidence of the occurrence of this species in the Balkans in the Early Neolithic.

Finally, the remains of amphibians (the frog Anura indet.) and reptiles (European green lizard Lacerta viridis) provide additional information on the past landscape (Tab. 3). The former generally inhabits marshy, wetland areas, whereas the latter is native to Southeastern Europe, preferring the dense, bushy vegetation in open woodland, fields, embankments and bramble thickets, and especially damp locations in the Southern Balkans.

The flotation of selected sediments at Vrbjanska Čuka also enabled the recovery of small and/or fragmented archaeological finds, such as pottery, stone and bone tool fragments, but also personal adornments. A fragmented bead made from marine shell was found in the flotated sample from Building 2. It is worth noting that similar beads have been known from other Early Neolithic sites in Macedonia, such as Amzabegovo and Vršnik ${ }^{64}$. These finds provide unique insights into the manners of bodily adornment among the inhabitants of Early Neolithic settlements in Macedonia, as well as their interconnections or indirect contacts with distant, coastal communities.

\section{Organic residue extraction and analyses}

One of the most informative approaches to unravel the uses of prehistoric vessels and diet is the application of GC, GC-MS and GC-C-IRMS to study the lipids extracted from the pottery matrix ${ }^{65}$. Throughout the lifetime of a pottery vessel, lipid molecules enter the microscopic pores of the unglazed prehistoric ceramic. This especially occurs during heat treatment (cooking). The micro-pores present an isolated environment, preserving this organic material until today and, with the help of modern technology, the prehistoric residue from the pottery can be extracted. Through chemical and isotopic analyses, we can identify the food products processed in pottery containers thousands of years ago. The importance of this information is manifold; pots used for cooking are easily identified.

63 Locker 2018; Cucchi et al. 2011.

64 Dimitrijević et al. in press.

65 Dudd/Evershed 1998; Evershed 2008; Correa-Ascencio/Evershed 2014. 
Moreover, associations of pottery morpho-types with specific products and similar cooking patterns and kitchen preferences are revealed. But the principle importance of these analyses lies in the study of past diets, subsistence diversity and paleoenvironment ${ }^{66}$.

In this regard, 27 potsherds from Vrbjanska Čuka were selected for lipid analysis as part of a wider Balkan Neolithic research project and submitted for analysis at the Organic Geochemistry Unit at the University of Bristol ${ }^{67}$. Seven potsherds contained ancient lipids, which is the usual retrieval rate for the region ${ }^{68} \cdot{ }^{13} \mathrm{C}$ values measured from the palmitic and stearic fatty acids contained in the extract discriminate the animal origin fats into three groups: dairy, ruminant adipose and non-ruminant adipose (Fig. 18). Pure, non-ruminant (pork) lipids were not detected. Dairy fats were confirmed only in one small, red-slipped, polished ceramic bowl. Being the first direct evidence for milk processing in Macedonia, this potsherd was subjected to compound-specific radiocarbon dating, a novel method using the organic extract to obtain a direct absolute date for the pot and the associated context ${ }^{69}$. The obtained date has been presented above where the dates from the radiocarbon analysis are discussed.

Other animal products were identified in the Vrbjanska Čuka pottery as well (Fig. 18). Three vessels with different shapes were used for cooking ruminant animal meat, two of which also presented biomarkers for plant processing. Two other potsherds gave a mixed signal of ruminant and non-ruminant (pork) meat. Beside these potsherds, one necked jar contained remains from plant food processing without any traces of animal fats. This is direct evidence for the importance of cereals in the diet at Vrbjanska Čuka which had been inferred from querns, sickle blades, storage units and carbonized grains. The samples were also tested for aquatic product biomarkers and beeswax traces, but they were not detected.

The current study assemblage is too small for a wide statistical elaboration or pattern identification, but presents important initial information from organic residue analysis on the diet and subsistence diversity in Neolithic Pelagonia, providing a unique, close-up view of the early agricultural economy and society.

66 Evershed et al.2008; Dunne et al.2012; Cramp et al.2014; Salque et al.2015; Stojanovski et al. 2020b.

67 Stojanovski et al.2020a.

68 Whelton et al. 2018; Cramp et al. 2019.

69 Casanova et al. 2020.

\section{Photogrammetric reconstruction of the site and granary in Building 1}

As part of the complex multidisciplinary research methodology, a few terrestrial and airborne photo field surveys were made ${ }^{70}$. Using this data via the application of the methodology of photogrammetry, moderately and highly detailed 3D models (including high-resolution orthophotos and digital elevation models) were generated for the excavated area and for two particular structures from Building 2 (Fig. 19). The updated spatial data from a total station was missing, but the horizontal and the vertical distortion in the model as measured from the meter scales is negligible. Apart from these results, the possibilities and the limitations for the use of the 3D data in the advanced spatial analyses (horizontal and vertical sections cutting throughout different features at different places and elevations, also LCP-least cost path, view-shed and flood analyses) are tested with a high level of success. This was made as an effort to find the exact methodological approach which could cover all aspects of the complex archaeological site, from excavation and documentation, throughout research and protection and finally for its adequate presentation. Therefore, the use of GIS technology was considered.

A 3D IBM (Image Based Modeling) recording procedure was implemented as well for the acquisition of precise geometry of the daub structure - i.e., the massive granary in Building 1 at Vrbjanska Čuka (Fig. 20). The procedure included the collection of a total amount of 480 images, taken from various perspectives, to provide the best possible coverage of the whole structure. These images were later processed through specialized software with the purpose of providing a fully virtual, 3D-reconstructed feature of the granary, in scaled measurements, jointly with color data. Measurements for providing a scaled model were taken on-site; the average error reported was under $1 \mathrm{~mm}$, which is suitable for the purposes of general documentation.

The benefits of the IBM product are numerous: first and foremost, the granary structure is in need of reconstruction treatment, and the final product of IBM recording can serve as a pre-reconstruction snapshot of the feature's state (to be used for verification of successful reconstruction and conservation treatment). Nevertheless, there is a great potential in using the model for virtual reconstruction of the granary's context, its surroundings and usage in 3D modeling software. This field of research in archaeolog-

70 Naumov et al. 2018b; Naumov et al. 2018c; Naumov et al. in press. 


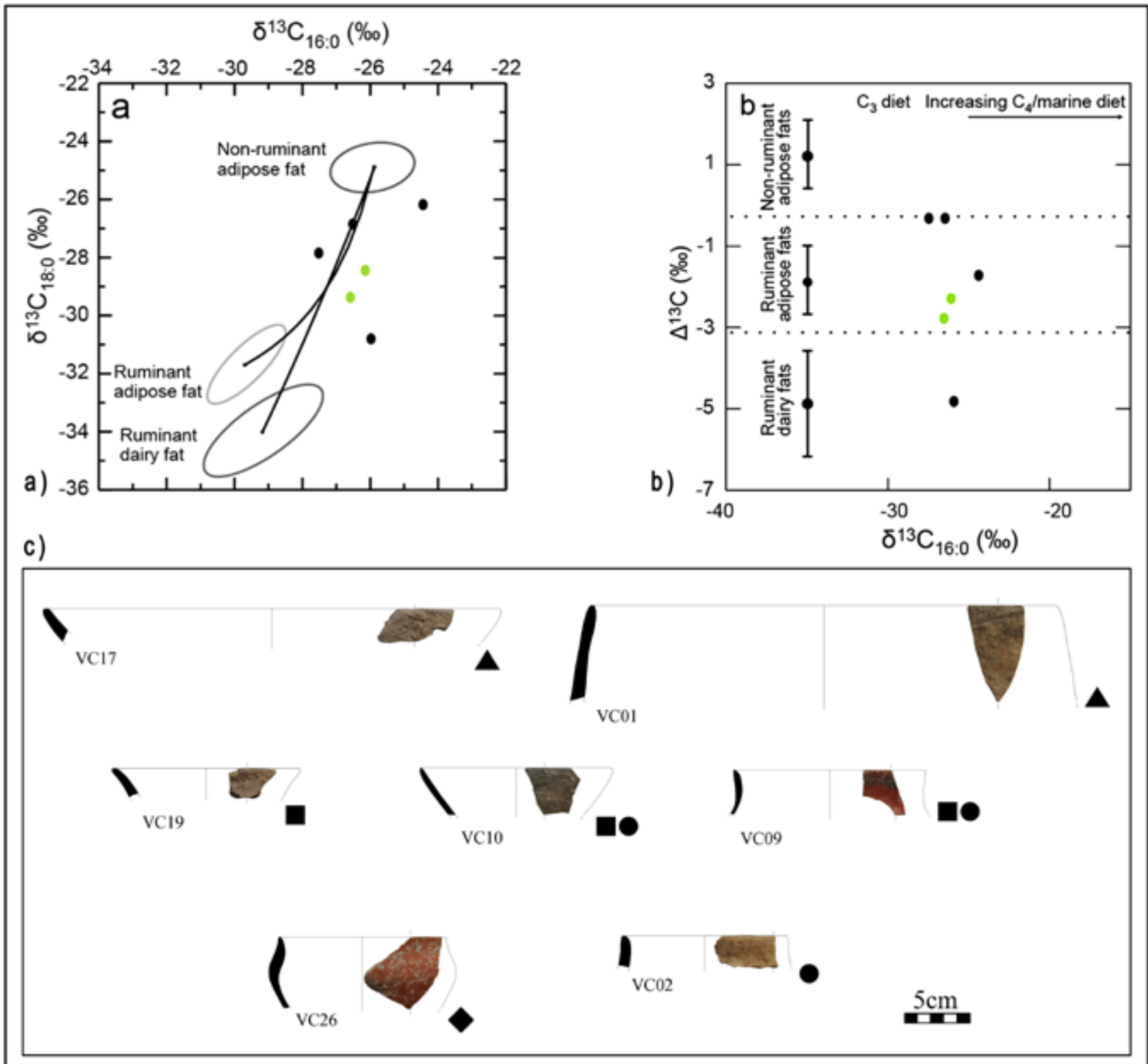

Fig. 18: $a: \delta^{13} C$ values for two fatty acids $\left(C_{16: 0}\right.$ and $\left.C_{18:}\right)$ for archaeological fats extracted from Vrbjanska Čuka, plotted against modern reference values from C3 diet raised animals in Britain (Copley et al. 2003); b: $\Delta^{13} C\left(\delta^{13} C_{18: 0-} \delta^{13} C_{16: 0}\right)$ values for the same Vrbjanska Čuka samples. The ranges shown here represent the mean $\pm 1 \mathrm{~s}$. d. of the $\Delta^{13} \mathrm{C}$ values for a global database comprising modern reference animal fats from Africa, UK (animals raised on a pure $C_{3}$ diet) Kazakhstan, Switzerland and the Near East (Dudd \& Evershed 1998; Spangenberg et al. 2006; Outram et al. 2009; Dunne et al. 2012); c: The ceramic vessels from Vrbjanska Čuka containing ancient lipids. The triangle marks a ruminant/non-ruminant adipose fat mixture, the square marks ruminant adipose fat, the circle marks plant processing and the diamond stands for dairy fats (Graphs and drawings: Darko Stojanovski and Stefanija Stojanovska).

ical practice has become more prominent in the past years as the technology for 3D scanning is affordable to a wide audience of professionals and amateurs. As a logical extension of the 3D scanning, the virtual reconstruction and presentation of archaeological cultural heritage contributes an important aspect of public outreach - especially when there is an interpretation gap between non-specialist viewers and the importance of objects of heritage.
The aforementioned data will be used for similar purposes, as the granary is one of the best-known architectural symbols of Neolithic Macedonia and more valuable research content from this endeavor still remains to be tackled and presented to the scientific community and general audiences alike. Besides the photogrammetry of the granary, a 3D model of anthropomorphic miniature house was also generated. The model enables 


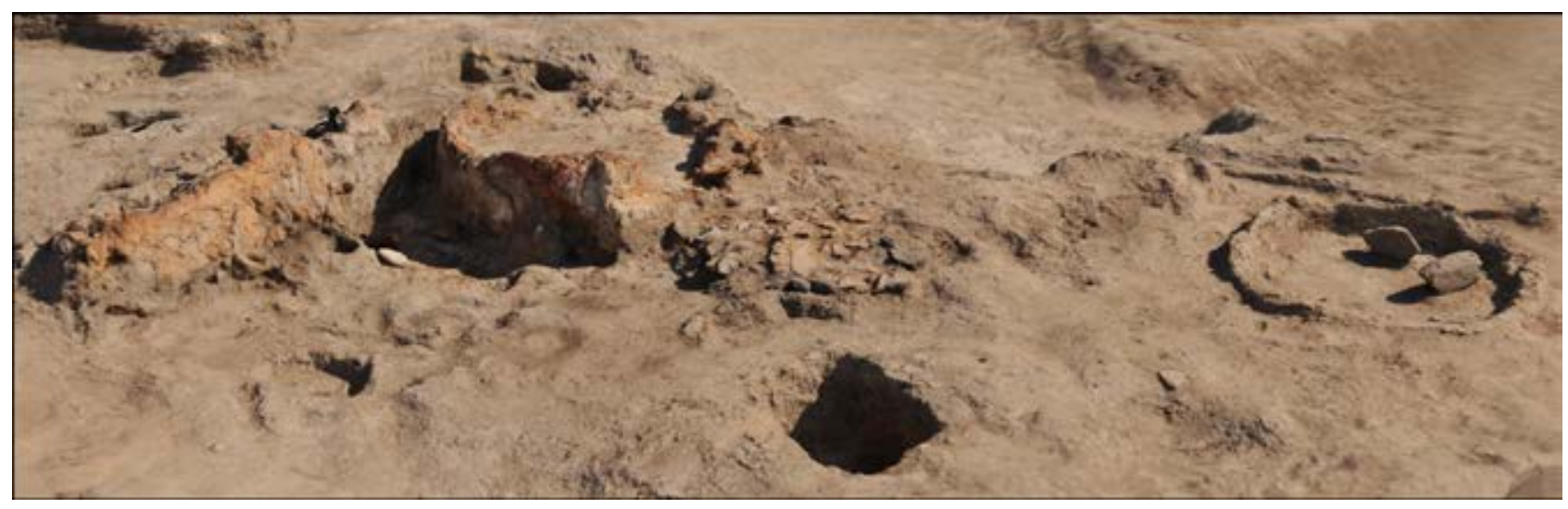

Fig. 19: 3D model made with photogrammetry and orthophoto images of the Oven 47 and structures for storing and processing cereals in the Building 2 (Illustration: Hristijan Talevski).

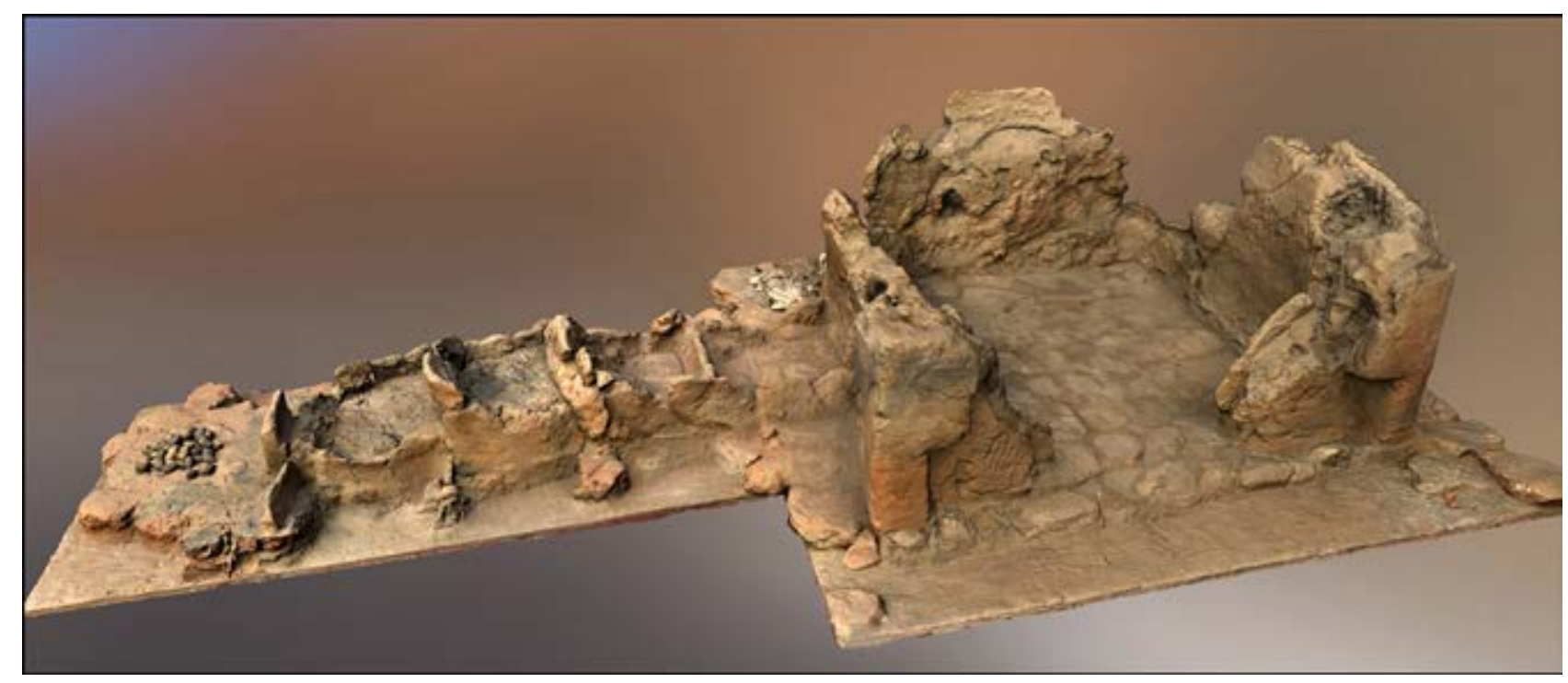

Fig. 20: 3D Image Based Modeling of the granary in the Building 1 (Illustration: Jugoslav Pendić).

a permanent approach to this find and study of its features by digital manipulation of its exterior and interior. Apart from its scientific potential, this model is also used for the presentation of the finds from Vrbjanska Čuka and their interaction with a wider group of viewers.

Another method also applied was a site-wide scan using an infrared scanner, which provides 3D presentation of the archaeological trench and its features. This method was used for the purpose of documentation and study of particular contexts while the research team is out of the trench, but also for a more tangible presentation of the site. As a result, the 3D presentation was labeled with information tags related to the site and with some of the most distinct architectural units. The 3D presentation was also adjusted for the employment of the Core VR equip- ment which enables a virtual reality visit to the site and the archaeological trench in particular. ${ }^{71}$

\section{Conclusion}

The current research of Vrbjanska Čuka is being performed in the same central area of the tell as in the 1980s excavations, but has introduced much more significant data on the stratigraphy, architecture and the economy of the Neolithic settlement. This is due to the multidisciplinary approach, but also as a result of thorough recording of

71 Naumov et al. in press. 
all archaeological features. Apart from the employment of the basic methods and the study of finds, this research also involves geomagnetic scanning, digital topography, archaeobotany, archaeozoology, radiocarbon dating, geoarchaeology, lipid, isotope and use-wear analyses, as well as 3D modeling of the trench, structures and artifacts with photogrammetry and drone orthophotography. All these components of the research enabled a comprehensive understanding of the Neolithic settlement at Vrbjanska Čuka and the community which established the tell and continuously lived there for several hundred years.

Although the tell as a whole is approximately $3.5 \mathrm{~m}$ high, the stratigraphy indicates $1.1 \mathrm{~m}$ of Neolithic levels in three horizons determined by the architectural features and not by material culture. A further revision of the Neolithic horizons will be necessary upon extending the archaeological trench and putting together a detailed insight into the material culture and the architectural features which would potentially be found. Even though ceramic vessels - the most frequent finds - do not bear significant differences between the initial and latest $\mathrm{Ne}$ olithic horizon at Vrbjanska Čuka, if examined further, they could still contribute towards an even more thorough understanding of the changes in this settlement, but also within the agricultural society. In this regard, radiocarbon analyses provide a closer look into the chronology of the settlement currently dated in the range of 6000 and 5700 CalBC as a temporal span between the beginning and end of the Neolithic settlement. So far, this date places the site in the final phases of the Early Neolithic, completely corresponding to the dating of several other sites in Pelagonia. The dating of the selected samples from each Neolithic layer to determine the chronological sequence of the entire Neolithic settlement is one of the aims of the forthcoming study seasons.

The architectural features discovered so far are typical for the Neolithic in the Balkans, consisting of six buildings built atop one another in three architectural horizons with a total of 14 buildings discovered in the entire archeological trench (although 17 were recorded in total, some belong to a single unit). Some of these buildings contain construction elements previously not asserted or discussed in the study of the Macedonian Neolithic. Namely, apart from the standard, burnt, massive daub common for Buildings $1-4,6$ and 9, the remaining buildings such as Buildings $7,8,10-14$ and 16 were made of dried daub that was not exposed to fire, i.e. was not burnt during their construction or prior to their abandonment. Building 5 was made of massive wooden posts with no daub, therefore it can be identified as an individual wooden structure or as an eave component of the Building 2. Building 14 has deep channel foundations where the posts have been inserted, whereas Building 15 could have also functioned as a pit dwelling or was used as a structure for economic purposes. The variety of architectural features at Vrbjanska Čuka indicates that there were at least four different types of buildings with a number of larger and smaller grannaries, bins, ovens and platforms made of daub in their interior. Some were cleared before the abandonment and numerous grinding stones were found upside down, referring to symbolic activities associated with the final stages of the buildings. Nevertheless, the large quantity of clay installations and grinding tools demonstrate the intensive processing of crops and an economy focused on agriculture.

In order to determine the scopes of the farming economy and crop processing in particular, use-wear and archaeobotanical analyses were performed that confirmed the presence of sickles, but also of einkorn wheat, emmer wheat, barley, lentils, peas, as well as a variety of gathered wild fruits used in the diet. The intensity of use of the sickle blades and the high amounts of cereal chaff present in building deposits suggest that agriculture was a very important activity associated with the inhabitants of the excavated structures and that the processing of agricultural products was a daily task that defined the functionality of certain spaces in the buildings. The storage of cereals is also corroborated by the remains of house mouse, which, to the best of our knowledge, represent the first evidence of the presence of this commensal species in Europe. Regarding the economy and animal products, the results of lipid analyses confirm the use of dairy products, animal meat and plant food, whereas the results of archaeozoological analysis suggest a mixed cattle and caprovine (and, to a lesser extent, pig) herding strategy, with an additional food supply of freshwater mussels, fish, wild game, and possibly waterfowl. The bioarchaeological and geoarchaeological studies also provide insight into the past environment of the site; i. e. the presence of certain elements of floral and faunal taxa is indicative of slow-flowing waters (wetlands) near Vrbjanska Čuka, but also forests (with oak and pine wood used in the settlement).

Considering the data obtained by the excavation, dating, laboratory analyses and material culture studies, it can be proposed that Vrbjanska Čuka was settled in the Early Neolithic by farming communities with exceptionally high aesthetic skills and knowledge of multiple techniques for building constructions and production of household items. This is additionally manifested by the exquisitely made fine ceramic vessels and their frequency within ceramic production, as well as by several buildings containing various architectural elements and decorated daub interior structures. The production of figurines, altar 
tablets and anthropomorphic house models indicates a symbolic perception of the human body and the embodiment of the domestic space as crucial for the establishment of solid relationship between several generations of inhabitants in the Neolithic settlement.

The results of the current research indicate that $\mathrm{Vr}$ bjanska Čuka is a complex site, especially when considering the data from the geomagnetic survey, which elaborates the presence of an enclosing ditch and a set of buildings organized in groups. It was a farming-oriented village set in an environment which attracted numerous Neolithic and Chalcolithic communities to establish their settlements, as confirmed by the reconnaissance and geomagnetic scanning of its surroundings where a number of other tells were recorded. The research of Vrbjanska Čuka is still ongoing, so the current multidisciplinary study of finds and organic remains, as well as the further excavation of buildings and new layers will provide significantly more information on the agricultural society that inhabited this tell in the northern parts of Pelagonia.

Acknowledgements: The authors wish to thank Viktorija Andreeska, Raül Soteras, Branko Risteski, Eli Milošeska, Toni Zatkoski, Zlate Korunoski, Zoran Kolčakoski, Andriana Dragović and the students of the Goce Delčev University and Ss. Cyril and Methodius University. The research of the site, material culture study and organic sample analyses were financially supported by the Ministry of Culture of North Macedonia, Municipality of Krivogaštani, European Research Council (Project BIRTH: Births, mothers and babies: prehistoric fertility in the Balkans between 10,000-5000 BC (Grant Agreement No. 640557), Spanish Ministry of Economy, Industry and Competitiveness (HAR2016-75201-P), University of Basel, Swiss National Science Foundation, Fritz Thyssen Foundation and the Prehistoric Society.

\section{Bibliography}

Allen/Gjipali 2014: S. Allen/I. Gjipali, New lights on the Early Neolithic in Albania: the Southern Albania Neolithic Archaeological Project (SANAP) 2006-2013, In: L. Përzhita/I. Gjipali/G. Hoxha/B. Muka (eds), Proceedings of the International Congress of Albanian Archaeological Studies, 65th Anniversary of Albanian Archaeology (Tirana 2014) 107-119.

Antolín/Jacomet 2015: F. Antolín/S. Jacomet, Wild fruit use among early farmers in the Neolithic (5400-2300 calBC) in the north-east of the Iberian Peninsula: an intensive practice? Vegetation History and Archaeobotany 24, 2015, 19-33. Antolin et al.2020: F. Antolín/A. Sabanov/G. Naumov/R. Soteras, Crop choice, gathered plants and household activities during the beginnings of farming in Pelagonia valley (North Macedonia). Antiquity 94 (376) (Project Gallery), 2020, 1-8 Arsovski 1991: M. Arsovski, Tectonic of Macedonia (Štip 1991). Beneš et al. 2018: J. Beneš/G. Naumov/T. Majerovičová/K. Budilová/

J. Bumerl/V. Komárková/J. Kovárník/M. Vychronová/

L. Juřičková, An Archaeobotanical Onsite Approach to the Neolithic Settlements in Southern Regions of the Balkans: The Case of Vrbjanska Čuka, a Tell Site in Pelagonia, Republic of Macedonia. Interdisciplinaria Archaeologica 9, 2018, 121-145. Bennison-Chapman 2019. L. Bennison-Chapman, Reconsidering 'Tokens': The Neolithic Origins of Accounting or Multifunctional, Utalitarian Tools? Cambridge Archaeological Journal 29/2, 2019, 233-259.

Bökönyi 1976: S. Bökönyi, The vertebrate fauna from Anza'. In: M. Gimbutas (ed.), Neolithic Macedonia as reflected by excavation at Anza, southeast Yugoslavia (Los Angeles1976) 315-363.

Bronk Ramsey 2017: C. Bronk Ramsey, Methods for Summarizing Radiocarbon Datasets. Radiocarbon 59/2, 2017, 1809-1833.

Bull/Payne 1982: G. Bull/S. Payne, Tooth eruption and epiphysial fusion in pigs and wild boar. In: B. Wilson, C. Grigson/S. Payne (eds), Ageing and sexing animal bones from archaeological sites (Oxford 1982) 55-71.

Carter/Magnell 2007: R. J. Carter/O. Magnell, Age estimation of wild boar based on molariform mandibular tooth development and its application to seasonality at the Mesolithic site of Ringkloster, Denmark'. In: U. Albarella/K. Dobney/A. Ervynck/ P. Rowley-Konwy (eds), Pigs and humans: 10,000 years of interaction (Oxford 2007) 197-217.

Casanova et al. 2020: E. Casanova/T. D. J. Knowles/A. Bayliss/ J. Dunne/M. Z. et al., Accurate compound-specific $14 \mathrm{C}$ dating of archaeological pottery vessels. Nature, 2020, [https://doi.org/10.1017/RDC.2020.11].

Chapman 2000: J. Chapman, Fragmentation in Archaeology: People, places and broken objects in the prehistory of South-eastern Europe (London 2000).

Chetwin 2007: J. Chetwin, The remains of wattle and daub structures. In: C. Higham (ed.), The Origins of the Civilization of Angkor volume 2: The Excavation of Noen U-Loke and Non Muang Ka (Bangkok 2007) 447-463.

Correa-Ascencio/Evershed 2014. M. Correa-Ascencio/R. P. Evershed, High throughput screening of organic residues in archaeological potsherds using direct acidified methanol extraction. Analytical Methods 6, 2014, 1330-40.

Cramp et al. 2014: L. J. E. Cramp/J. Jones/A. Sheridan/J. Smyth/ H. Whelton/J. Mulville/N. Sharples/R. P. Evershed, Immediate replacement of fishing with dairying by the earliest farmers of the northeast Atlantic archipelagos. Proceedings of the Royal Society B: Biological Sciences 281, 2014, 20132372.

- et al. 2019: -/J. Ethier/D. Urem-Kotsou/C. Bonsall/D. Borić/

A. Boroneanţ/R. P. Evershed/S. Perić/M. Roffet-Salque/ H. L. Whelton/M. Ivanova, Regional diversity in subsistence among early farmers in Southeast Europe revealed by archaeological organic residues. Proceedings of the Royal Society B: Biological Sciences 286, 2019, 20182347.

Cucchi et al. 2011: T. Cucchi/J. D. Vigne/J. C. Auffray, First occurrence of the house mouse (Mus musculus domesticus in the Western Mediterranean: a zooarchaeological revision of subfossil occurrences. Biological Journal of the Linnean Society $84 / 3$, 2011, 429-445. 
David et al. 2008: A. David/N. Linford/P. Linford, Geophysical Survey in Archaeological Field Evaluation (Swindon 2008).

Dimitrijević et al. in press: V. Dimitrijević/G. Naumov/S. Stefanović, A string of marine shell beads from the Neolithic site of Vršnik (Tarinci, Ovče pole), and other marine shell ornaments in the Neolithic of North Macedonia. Anthropozoologica (in press).Dudd/Evershed 1998: S. N. Dudd/R. P. Evershed, Direct Demonstration of Milk as an Element of Archaeological Economies. Science 282, 1998, 1478-81.

Dumurdzanov et al. 2004: -/T. Serafimovski/B. C. Burchfiel, Evolution of Neogene-Pleistocene Basins of Macedonia. Digital Map and Chart Series 1 (Accompanying notes) (Boulder 2004).

Dunne et al.2012: J. Dunne/R. P. Evershed/M. Salque/L. Cramp/S. Bruni/K. Ryan/S. Biagetti/S. Dilernia, First dairying in green Saharan Africa in the fifth millennium BC. Nature 486, 2012, 390-94.

Evershed 2008: R. P. Evershed, Organic residue analysis in archaeology: The archaeological biomarker revolution. Archaeometry 50, 2008, 895-924.

- et al. 2008:-/S. Payne/A. G. Sherratt/M. S. Copley et al., Earliest date for milk use in the Near East and southeastern Europe linked to cattle herding. Nature 455, 2008, 528-531.

Fidanoski 2015: Lj. Fidanoski, Home Sweet Home: Neolithic Architectural Remnants from Cerje-Govrlevo, Republic of Macedonia. Analele Banatului XXIII, 2015, 11-44.

Garašanin 1979: M. Garašanin, Centralnobalkanska zona. In: A. Benac (ed.) Praistorija Jugoslavenskih Zemalja II - Neolitsko doba (Sarajevo 1979) 79-212.

Gheorghiu 2007. D. Gheorghiu, Fire as An Instrument: The Archaeology of Pyrotechnologies (Oxford 2007).

Gibaja et al. 2017: J. F. Gibaja/J. J. Ibáñez/E. Nielsen/A. Kienholz/ S. van Willigen/J. Linton, The Neolithic reaping knives from Egolzwil 3: A Mediterranean technical tradition in the late 5th millennium Swiss Neolithic. Quaternary International 427, 2017, 211-224.

Gillis 2012: R. Gillis, Osteological and isotopic contributions to the study of dairy husbandry during the European Neolithic. Thèse de doctorat (Paris 2012).

Gimbutas 1974: M. Gimbutas, Anza, ca. 6500 - 5000 B.C.: Cultural Yardstick for the Study of Neolithic Southeast Europe. Journal of Field Archaeology 1/2, 1974, 27-66.

Grant 1982: A. Grant, The use of tooth wear as a guide to the age of domestic animals. In: B. Wilson, C. Grigson/S. Payne (eds), Ageing and sexing animal bones from archaeological sites (Oxford 1982) 91-108.

Grbić et al. 1960: M. Grbić/P. Mačkić/Š. Nadj/D. Simoska/B. Stalio, Porodin: kasno-neolitsko naselje na Tumbi kod Bitolja (Bitolj 1960).

Habermehl 1985: K. H. Habermehl, Altersbestimmung bei Wild- und Pelztieren (Hamburg, Berlin 1985).

Halstead et al. 2002: P. Halstead/P. Collins/V. Isaakidou, Sorting the sheep from the goats: morphological distinctions between the mandibles and mandibular teeth of adult Ovis and Capra. Journal of Archaeological Science 29/5, 2002, 545-553.

Hambleton 1999: E. Hambleton, Animal husbandry in Iron Age Britain: a comparative study of faunal assemblages from British Iron Age sites (Oxford 1999).

Ivkovska 2009: A. Ivkovska, Animal husbandry and hunting. In: G. Naumov/Lj. Fidanoski/l. Tolevski/A. Ivkovska Neolithic communities in the Republic of Macedonia (Skopje 2009)

53-63.

Jacomet et al. 1989: S. Jacomet/C. Brombacher/M. Dick, Archäobotanik am Zürichsee. Ackerbau, Sammelwirtschaft und Umwelt von neolithischen und bronzezeitlichen Seeufersiedlungen im Raum Zürich. Ergebnisse von Untersuchungen pflanzlicher Makroreste der Jahre 1979-1988 (Zürich 1989).

Jongsma 1997: T. Jongsma, Distinguishing pits from pit houses through daub analysis: The nature and location of Early Neolithic Starčevo-Criş houses ad Foeni-Salaş, Romania, MA thesis (Winnipeg 1997).

Kenward et al. 1980: H. K. Kenward/A. R. Hall/A. K. C. Jones, A tested set of techniques for the extraction of plant and animal macrofossils from waterlogged archaeological deposits. Science and Archaeology 22. 1980, 3-15.

Kitanoski 1977: B. Kitanoski, Neolitskata naselba Čuka kaj selo Topolčani. Macedoniae acta archaeologica 3, 1977, 27-42.

- 1989: -, Vrbjanska Čuka. Arheološki Pregled 28, 1989, 47-48.

- et al. 1990: -/D. Simoska/B. Jovanović, Der Kultplatz auf der Fundstätte Vrbjanska Cuka bei Prilep. In: Srejović, D. and Tasić, N. (eds), Vinča and its World. International Symposium The Danubian Region from 6000-3000 BC (Beograd 1990) 107-112.

Lasota Moskalewska 1985a: A. Lasota Moskalewska, Tumba I, S. Mogila. Katalog szcątków zwierzęcych. Neolit. Unpublished report (Warszawa 1985).

- 1985b. -, Tumba II, S. Mogila. Katalog szcątków zwierzęcych. Neolit. Unpublished report (Warszawa 1985).

-/Sanev 1989. -/V. Sanev, Preliminary analysis of bone remnants of animals from the Neolithic archaeological site Tumba Madžari near Skopje (Yugoslavia). Macedoniae acta archaeologica 10, 1989, 55-78.

Locker 2018: K. Locker, Mice in the Balkan Neolithic. MA dissertation (York 2018).

Manning et al. 2013: K. Manning/B. Stopp/S. Colledge/S. Downey/J. Conolly/K. Dobney/S. Shennan, Animal exploitation in the early Neolithic of the Balkans and central Europe. In: S. Colledge/J. Conolly/K. Dobney/K. Manning/S. Shennan (eds), Origins and Spread of Domestic Animals in Southwest Asia and Europe. Walnut Creek (2013) 237-252.

Marinova 2017: E. Marinova, Archaeobotanical analysis of the Neolithic site Bâlgarčevo, Southwestern Bulgaria. In: J. Lechterbeck/E. Fischer (eds), Kontrapunkte: Festschrift für Manfred Rösch (Bonn 2017) 147-158.

- et al. 2016:-/B. De Cupere/V. Nikolov, Preliminary results of the bioarchaeological research at the Neolithic site of Mursalevo (South-West Bulgaria): evidence on food storage, processing and consumption from domestic contexts. In: K. Bacvarov/ R. Gleser (eds), Southeast Europe and Anatolia in prehistory. Essays in honor of Vassil Nikolov on his 65th anniversary (Bonn 2016) 509-526.

Matschke 1967: G. H. Matschke, Ageing European wild hogs by dentition. Journal of Wildlife Management 29 (1967) 109-113.

Mazăre 2012: N. P. Mazăre, The Craft of Textile Production at the Neolithic and Eneolithic Communities in Transylvania, PhD thesis (Alba Iulia 2012).

Mazzucco et al.2017: N. Mazzucco/G. Capuzzo/C. Petrinelli Pannocchia/J. J. Ibáñez/J. F. Gibaja, Harvesting tools and the spread of the Neolithic into the Central-Western Mediterranean area. Quaternary International 470, 2018, 511-528. 
Misiewicz 2006: K. Misiewicz, Geofizyka archeologiczna (Warszawa 2006).

Mitkoski 2005: A. Mitkoski, Vrbjanska Čuka kaj seloto Slavej, Prilepsko. Zbornik na Muzejot na Makedonija 2, 2005, 33-46.

Mitkoski/Naumov 2007:-/G. Naumov. Neolithic Structure of possible ritual significance from The Republic of Macedonia. PAST 58, 2007, 8-9.

Naumov 2013: G. Naumov, Embodied houses: social and symbolic agency of Neolithic architecture in the Republic of Macedonia. In: D. Hoffman/J. Smyth (eds), Tracking the Neolithic house in Europe - sedentism, architecture and practice (New York 2013) 65-94.

- 2015: -, Early Neolithic Communities in Macedonia. Archeologické Rozhledy LXVII/3, 2015, 331-355.

- 2016a: -, Tell communities and wetlands in the Neolithic Pelagonia, Republic of Macedonia. Documenta Praehistorica 43, 2016, 327-342.

- 2016b: -, Kalibrirana hronologija na neolitskite tumbi vo Pelagonija. In: Lj. Fidanoski/G. Naumov (eds), Neolit vo Makedonija: novi soznanija i perspektivi (Skopje 2016).

- 2020: -, Domestication of Tells: settlements of the first farmers in Pelagonia. In: A. Blanco Gonzales/L. T. Kienlin (eds), Current approaches to tells in the prehistoric Old World, (Oxford 2020), 111-124.

-/Tomaž 2015: -/A. Tomaž, The Excavation of Neolithic Tell in Mogila, Pelagonia. Patrimonium 13, 2015, 67-95.

- et al. 2014: -/M. Trzeciecki/M. Chwiej/M. Przybyła/M. Bugaj/P. Szczepanik/M. Podsiadto, Arheološko, topografsko i geofizičko istražuvanje na neolitski tumbi vo Pelagonija. Patrimonium 12, 2014, 345-372.

- et al. 2017a: -/A. Mitkoski/A. Murgoski/G. Milevski, Reconnaissance of Prehistoric Sites in North Pelagonia. Patrimonioum 15, 2017, 11-36.

- et al. 2017b: -/J. John/O. Chvojka 2017, Geophysical scanning of prehistoric tells in Central Pelagonia. In: Lj. Fidanoski/G. Naumov (eds), Neolithic in Macedonia: step forward in the study of the first farming societies (Skopje 2017) 161-180.

- et al. 2018a: -/A. Mitkoski/A.Murgoski/J.Beneš/M.Przybila/G. Milevski/V. Komarkova/M. Vychronova/I. Stoimanovski, Multidisciplinary Research at the Vrbjanska Čuka site near Slavej in Pelagonia - 2016, Archaeologia Adriatica 12, 2018, 99-141.

- et al. 2018b: -/A. Mitkoski/H.Talevski/A. Murgoski/J. Beneš/ I. Živaljević/J. Pendić/D. Stojanoski/F. J. Gibaja/N. Mazzucco/ A. Hafner/S. Szidat/V. Dimitrijević/S. Stefanović/K. Budilova/ M. Vychronova/T. Majerovičova/J. Bumerl, Research on the Vrbjanska Čuka site in 2017. Balcanoslavica 47/1, 2018, 253-285.

- et al. 2018c: -/A. Mitkoski/H.Talevski, Excavation Season in 2018 at Vrbjanska Čuka tell in Pelagonia. In: Lj. Fidanoski/G. Naumov (eds), Neolithic in Macedonia: Challenges for New Discoveries (Skopje 2018) 35-55.

- et al. in press: -/A. Mitkoski/H.Talevski/D. Stojanovski/ V. Andreeska/P. Stamatoska/Z. Kovačevski, Research on the Vrbjanska Čuka site at Slavej in 2019. Macedoniae acta archaeologica 25, (in press).

Nilhamn 2002. B. Nilhamn, Tokens of Identity? Small Clay Objects in Near Eastern Archaeology (Uppsala 2002).

Özdemir 2007: A. Özdemir, An Experimental Study of Mat Impressions on Pot Bases from Chalcolithic Gülpınar
(Smintheion). In: T. Takaoğlu (ed), Ethnoarchaeological Investigations in Rural Anatolia 4 (Istanbul 2007) 73-85.

Payne 1985: S. Payne, Morphological distinctions between the mandibular teeth of young sheep, Ovis, and goats, Capra. Journal of Archaeological Science 12/2, 1985, 139-147.

Pazdur 1990: M. Pazdur, Datiranje na organskite primeroci od arheološko-konzervatorskite istražuvanja so radiokarbonova metoda $\mathrm{C}^{14}$. In: L. Krzizanowski (ed.) Tvrdinata Markovi Kuli: izveštai od rabotata na misijata 1984-1988 (Warsawa 1990), 70-75.

Ramsey et al. 2013: C. Bronk Ramsey/M. Scot/H. van der Plicht, Calibration for archaeological and environmental terrestrial samples in time range 26-50 ka CalBC. Radiocarbon 55, 2013, 2021-2027.

Reingruber/Thissen 2016: A. Reingruber/L. Thissen The 14SEA Project: $\mathrm{a}^{14} \mathrm{C}$ database for Southeast Europe and Anatolia (10,000-3000 calBC). http://www.14sea. org/index.html [last accessed May 2020].

Ristić 1977: M. Ristić, Ribe i ribolov u slatkim vodama (Beograd 1977).

Salque et al. 2015: M. R. Salque/M. Regert/R. P. Evershed/ A. K. Outram et al., Widespread exploitation of the honeybee by early Neolithic farmers. Nature, 2015, 527: 226-30.

Sanev 1994: V. Sanev, Mlado kameno vreme. In D. Koco (ed.) Arheolośka karta na Republika Makedonija - Tom I (Skopje 1994) 26-42.

- 1995: -, Neolitot i neolitskite culturi vo Makedonija. In: G. Stardelov et al. (eds), Civilizacii na poćvata na Makedonija 2 (Skopje 1995) 21-46.

Schwartz 1976: C. A. Schwartz, The vertebrate fauna from Rug Bair', in M. Gimbutas (ed.) Neolithic Macedonia as reflected by excavation at Anza, southeast Yugoslavia (Los Angeles 1976) 364-374.

Sherard 2009: J. Sherard, Analysis of Daub from Mound V, Moundville: Its Role as an Architectural Indicator. Bulletin of the Alabama Museum of Natural History 27, 2009, 29-42.

Silver 1969: I. A. Silver, The ageing of domestic animals. In: D. Brothwell/E. Higgs (eds), Science in Archaeology: A Comprehensive Survey of Progress and Research (London 1969) 283-302.

Simoska/Sanev 1975: D. Simoska/V. Sanev, Neolitska naselba Veluśka Tumba kaj Bitola. Macedoniae acta archaeologica 1, 1975, 25-85.

- /Sanev 1976: -/V. Sanev, Praistorija vo Centralna Pelagonija (Bitola 1976).

- /Sanev 1977: -/V. Sanev, Neolitska naselba na Mala Tumba kaj selo Trn, Bitola Macedoniae acta archaeologica 3, 1977, 215-237.

- et al. 1979: -/B. Kitanoski/J. Todorović, Neolitska naselba vo selo Mogila kaj Bitola. Macedoniae acta archaeologica 5, 1979, 9-30.

- /Kuzman 1990: -/P. Kuzman, Tumba Optičari. Arheološki Pregled 1988, 1990, 63-66.

Srdoć et al. 1977: D. Srdoč/A. Sliepčević/B. Obelić/N. Horvatinčić/ R. Bošković,. Radiocarbon measurements IV. Radiocarbon 19/3, 1977, 465-475.

Stefanović 1997: M. Stefanović, The Age of Clay: The Social Dynamics of House Destruction. Journal of Anthropological Archaeology 16, 1997, 334-395. 
Steiner et al. 2015: B. L. Steiner/F. Antolín/S. Jacomet, Testing of the consistency of the sieving (wash-over) process of waterlogged sediments by multiple operators. Journal of Archaeological Science: Reports 2, 2015, 310-320.

Stojanović/Obradović 2016: I. Stojanović/Đ. Obradović, Integrating archaeozoological and archaeobotanical data: different perspectiveson past food practices. Case study: The Early Neolithic context from Drenovac, central Serbia. In: S. Perić (ed.), The Neolithic in the Middle Morava Valley. No 2. Institute of Archaeology (Belgrade 2016) 79-102.

Stojanovski et al.2020a: D. Stojanovski/I. Živaljević/V. Dimitrijević/J. Dunne/R. P. Evershed/M. Balasse/A. Dowle/C. Speller/J. Hendy/R. Fischer/C. Speller/J. Jovanović/E. Casanova/T. Knowles/L. Balj/G. Naumov/A. Putica/A. Starović/S. Stefanović, The Living off the land: Terrestrial based diet and dairying in the farming communities of the Neolithic Balkans. PLOS One 15(8), 2020, 1-18.

- et al. 2020b: -/M. Roffet-Salque/E. Casanova/T. Knowles/L. Oosterbeek/R. P. Evershed/A. Cruz/L. Thissen/M. Arzarello, Anta 1 de Val da Laje - the first direct viewat diet, dairying practice and socio-economic aspects of pottery use in the final Neolithic of central Portugal. Quaternary International [https:// doi.org/10.1016/j.quaint.2020.02.016].

Temelkoski 1999: D. Temelkoski, Eneolitska naselba Krušeanska Čuka, Macedoniae acta archaeologica 15, 1999, 33-45.

-/Mitkoski 2005: -/A. Mitkoski, Sadova keramika od Vrbjanska Čuka, Macedoniae acta archaeologica 16, 2005, 29-53.

Trifunovski 1998: J. Trifunovski, Bitoljsko-prilepska kotlina: antropogeografska proučavanja (Beograd 1998).
Tringham 2005: R. E. Tringham, Households with Faces: The Challenge of Gender in Prehistoric Architectural Remains. In: J. M. Gero/M. Conkey (eds), Engendering archaeology. Women and Prehistory (Oxford 1991) 93-131.

Valastro et al. 1977: S. Valastro/J. E. Mott Davis/A. G. Varela, University of Texas at Austin: Radiocarbon dates 11. Radiocarbon 19/2, 1977, 280-325.

Vigne/Helmer 2007: J. D. Vigne/D. Helmer, Was milk a „secondary product" in the Old World Neolithisation process? Its role in the domestication of cattle, sheep and goats. Anthropozoologica 42/2, 2007, 9-40.

Westcott/Brandon 2000: K. L. Westcot/R. J. Brandon, Practical applications of GIS for archaeologists: a predictive modellingkit (London 2000).

Wheatley/Gillings 2002: D. Wheatley/M. Gillings, Spatial Technology and Archaeology: a Guide to the Archaeological Applications of GIS (London 2002). Whelton et al. 2018: H. L. Whelton/M. Roffet Salque/K. Kotsakis/D. Urem Kotsou/ R.P. Evershed, Strong bias towards carcass product processing at Neolithic settlements in northern Greece revealed through absorbed lipid residues of archaeological pottery. Quaternary International 496, 2018, 127-39.

Živaljević et al. 2017: I. Živaljević/V. Dimitrijević/S. Stefanović, Faunal remains from Kula, a Mesolithic-Neolithic site at the exit of the Danube Gorges (Serbia). In: M. Mărgărit/A. Boroneanț (eds), From Hunter-Gatherers to Farmers: Human Adaptations at the End of the Pleistocene and the First Part of the Holocene. Papers in Honour of Clive Bonsall (Târgovişte 2017) 113-133. 